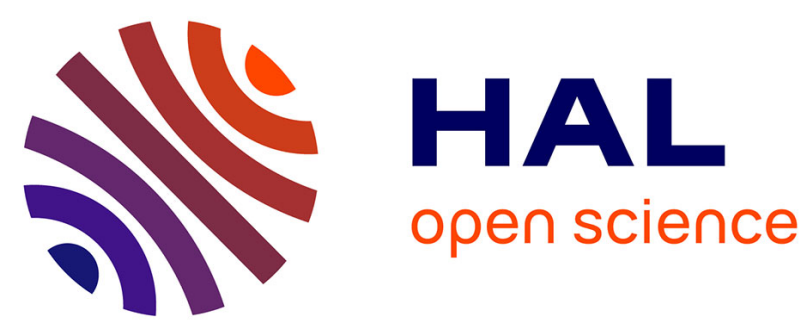

\title{
Subduction zone intermediate-depth seismicity: Insights from the structural analysis of Alpine high-pressure ophiolite-hosted pseudotachylyte (Corsica, France)
}

Rémi Magott, Olivier Fabbri, Marc Fournier

\section{- To cite this version:}

Rémi Magott, Olivier Fabbri, Marc Fournier. Subduction zone intermediate-depth seismicity: Insights from the structural analysis of Alpine high-pressure ophiolite-hosted pseudotachylyte (Corsica, France). Journal of Structural Geology, 2016, 87, pp.95-114. 10.1016/j.jsg.2016.04.002 . hal01346160

\author{
HAL Id: hal-01346160 \\ https: / hal.sorbonne-universite.fr/hal-01346160
}

Submitted on 18 Jul 2016

HAL is a multi-disciplinary open access archive for the deposit and dissemination of scientific research documents, whether they are published or not. The documents may come from teaching and research institutions in France or abroad, or from public or private research centers.
L'archive ouverte pluridisciplinaire HAL, est destinée au dépôt et à la diffusion de documents scientifiques de niveau recherche, publiés ou non, émanant des établissements d'enseignement et de recherche français ou étrangers, des laboratoires publics ou privés. 
1 Subduction zone intermediate-depth seismicity: Insights from the structural analysis of 2 Alpine high-pressure ophiolite-hosted pseudotachylyte (Corsica, France).

3

4 Rémi Magott $^{1}$, Olivier Fabbri ${ }^{1 *}$ and Marc Fournier ${ }^{2}$

Email : Remi.Magott@univ-fcomte.fr; olivier.fabbri@univ-fcomte.fr

Email : marc.fournier@upmc.fr

* Corresponding author: olivier.fabbri@univ-fcomte.fr

Highlights

\section{ABSTRACT}

1 : UMR CNRS 6249 Chrono-environnement, Université Bourgogne Franche-Comté, Besançon, France

2 : Sorbonne Universités, UPMC Univ. Paris 06, UMR 7193, ISTEP, F-75005 Paris, France

Alpine Corsica ophiolite pseudotachylyte formed in a subducting oceanic lithosphere

Displacement sense associated with pseudotachylyte fault veins is determined

Corsican ruptures are similar to seismic ruptures in Pacific plate beneath NE Japan

Pseudotachylyte in the Cima di Gratera ophiolite, Alpine Corsica, is distributed in the peridotite unit and in the overlying metagabbro unit and was formed under blueschist to eclogite metamorphic facies conditions, corresponding to a 60-90 km depth range. Peridotite pseudotachylyte is clustered in fault zones either beneath the tectonic contact with overlying metagabbros or at short distance from it. Fault zones are either parallel to the contact or make an angle of $55^{\circ}$ to it. Displacement sense criteria associated with fault veins indicate top-tothe-west or top-to-the-northwest reverse senses. Cataclasite flanking most veins was formed before or coevally with frictional melting and likely mechanically weakened the peridotite, facilitating subsequent seismic rupture. In the basal part of the metagabbro unit, postmylonitization pseudotachylyte can be distinguished from pre-mylonitization pseudotachylyte formed earlier. In the equant metagabbro above the mylonitic sole, only one episode of pseudotachylyte formation can be identified. Kinematics associated with metagabbro pseudotachylyte remain unknown. The geometry and kinematics of the pseudotachylyte veins from the peridotite unit and to a lesser extent from the metagabbro unit are similar to modern 
seismic ruptures of the upper parts of the Wadati-Benioff zones such as in the Pacific plate beneath NE Japan.

\section{KEYWORDS}

\section{Pseudotachylyte, intermediate-depth seismicity, peridotite, metagabbro, subduction, Alpine Corsica}

\section{Introduction}

Subduction zone seismicity consists mainly of shallow 'megathrust-type' earthquakes (focal depths $<60 \mathrm{~km}$ ), intermediate-depth earthquakes (focal depths between 60 and $300 \mathrm{~km}$ ), and deep-focus earthquakes (focal depths $>300 \mathrm{~km}$ ). Events from the first category typically nucleate and propagate at the interface between the two lithospheric plates, while those from the last two categories nucleate in the crust or the mantle of the subducting slab. In subduction zones, the most destructive earthquakes are those from the first category. Their hypocenters can be shallow, their magnitudes can reach or exceed 8, and they can trigger tsunamis. Though less spectacular, intermediate-depth earthquakes still represent a significant threat because of the proximity of their epicenters with major cities and also because of infrequent but high magnitudes. Events illustrating such hazards include the 1939 Chile earthquake (Frohlich, 2006) or the 2001 El Salvador earthquake (Vallée et al., 2003; Martinez-Diaz et al., 2004).

In subduction zones, the hypocenters of intermediate-depth earthquakes tend to be clustered along a so-called Wadati-Benioff seismic zone. In most cases, precise hypocentral locations allow to divide the Wadati-Benioff seismic zone into two sub-zones. The separation between the two sub-zones is comprised between 8 and $30 \mathrm{~km}$ and is a function of the age of the subducting plate (Hasegawa et al., 1978a and b, 2009; Yoshii, 1979; Kao and Chen, 1995; Kao and Liu, 1995; Seno and Yamanaka, 1996; Brudzinski et al., 2007). The upper sub-zone appears to be located in the crust and/or in the uppermost part of the underlying mantle, while the lower sub-zone lies entirely in the mantle (Igarashi et al., 2001; Preston et al., 2003; Abers et al., 2013; Nakajima et al., 2013).

Pseudotachylyte exposed in Cape Corse (Alpine Corsica, France) is of tectonic origin and was generated under blueschist to eclogite facies metamorphic conditions (Austrheim and Andersen, 2004; Andersen and Austrheim, 2006; Andersen et al., 2008, 2014; Deseta et al., 2014a and b). As such, it was likely formed in Cretaceous to Paleogene times in the WadatiBenioff seismic zone of a subducting Tethysian lithosphere. The aim of this contribution is to analyze the geometry of the pseudotachylyte fault veins and the kinematics during their 
formation. The results of this analysis then allows a comparison between the fossil Corsican Cretaceous to Paleogene seismic ruptures and present-day Wadati-Benioff seismic zones observed in cold slabs such as the Pacific plate beneath NE Japan.

\section{Geological setting and structure of the study area}

\subsection{General setting}

Alpine Corsica is a segment of the Alpine orogen which displays an imbrication of thrust sheets composed of rocks of various origins and variably deformed and metamorphosed. Peridotite, serpentinite, gabbro, basalt, calcareous schist, siliceous schist and marble represent remnants of the lithosphere of the Jurassic Piemonte-Liguria oceanic basin and its pelagic sedimentary cover. Radiometric dating of the oceanic peridotites and gabbros yielded Middle to Late Jurassic ages between 169 and 152 Ma (Ohnenstetter et al., 1981; Rossi et al., 2002; Rampone et al., 2009; Li et al., 2015). Several observations indicate that the spreading ridge of the Piemonte-Liguria basin was of slow to very slow type (Rampone and Piccardo, 2000; Piccardo, 2008; Manatschal and Müntener, 2009).

Crystalline thrust sheets (composed mainly of orthogneisses) and proximal sedimentary deposits are interpreted as fragments of the stretched European continental paleo-margin and its sedimentary cover (Vitale-Brovarone et al., 2011, 2014; Meresse et al., 2012). The imbrication of such a variety of rocks is classically interpreted as the result of an eastwarddipping Cretaceous subduction of the Piemonte-Liguria oceanic basin and a part of the stretched European margin beneath the continental lithosphere of Apulia followed by an Eocene collision between the European and Apulian continental lithospheres (Mattauer and Proust, 1976; Mattauer et al., 1977, 1981; Warburton, 1986). Initiation of the subduction is poorly dated. Paleogeographic reconstructions suggest a Late Cretaceous age (Stampfli et al., 1998), but Late Cretaceous absolute ages of the HP metamorphism suggest that subduction started in Middle Cretaceous times or earlier. The ophiolite-bearing Schistes Lustrés nappe complex lies between the two blocks involved in the collision.

The classical Alpine evolutionary models were modified by taking into account the Apennine orogeny (e.g., Durand-Delga and Rossi, 2002). Several authors suggested that the eastdipping Cretaceous subduction ceased in Paleocene-Early Eocene times and was followed by a west-dipping subduction of a young oceanic lithosphere of a back-arc basin formed further east (Jolivet et al., 1998; Lacombe and Jolivet, 2005; Molli, 2008; Molli and Malavieille, 2010; Agard and Vitale-Brovarone, 2013). Based on new Late Eocene HP metamorphism 
ages, Vitale-Brovarone and Herwartz (2013) suggest that the subducting oceanic plate now preserved as ophiolitic thrust sheets and nappes in Alpine Corsica was of 'Apennine' affinity, i.e., was dipping westward since the very beginning of the convergence. These authors however acknowledge that more datings are needed before invalidating the eastward-dipping ('Alpine') subduction. In this paper, the Late Cretaceous to Early Tertiary oceanic subduction will be considered as an Alpine-type east-dipping subduction, before it is replaced by a westdipping Apennine-type subduction in Middle Eocene times.

A large part of Alpine Corsica rocks suffered from a high pressure-low temperature (HP-LT) blueschist to lawsonite-eclogite facies metamorphism (Ravna et al., 2010; Vitale-Brovarone et al., 2013 and references therein). This HP-LT metamorphism is of Eocene age (55-34 Ma, Brunet et al., 2000; Martin et al., 2011; Maggi et al., 2012; Vitale-Brovarone and Herwartz, 2013) and is interpreted as the result of the subduction of continental or oceanic units at great depths. A retrograde greenschist facies metamorphism is also recorded in some units and is interpreted as the consequence of a late- to post-orogenic extension during late Oligocene to early Miocene times (Jolivet et al., 1990, 1991, 1998; Fournier et al., 1991).

Non-metamorphic tectonic units (so-called upper or superficial nappes) lie at the top of the structural stacking of thrust sheets. These units consist of sedimentary strata mostly of Jurassic to Eocene age and ophiolitic rocks and related deposits. The rocks constituting these superficial nappes were likely formed or deposited on the margin of the Apulian continent (or an intervening island arc or micro-block) and subsequently transported westward during the collision above the metamorphic units.

Structures associated with the ductile non-coaxial deformation of the metamorphic units include a widespread foliation, various folds (including sheath folds) and a pervasive E-W stretching and mineral lineation. The sense of shear associated with the non-coaxial deformation during the prograde metamorphism is top-to-the-west (Mattauer et al., 1977, 1981; Faure and Malavieille, 1981; Harris, 1985; Warburton, 1986) whereas that associated with the retrograde metamorphism and the late- to post-orogenic extension is mainly top-tothe east (Fournier et al., 1991; Jolivet et al., 1990, 1991). The late- to post-orogenic extension is also attested by numerous normal faults striking around N-S and dipping eastwards or westwards.

\subsection{Structure of the study area}


The study area is located in the southern part of the Cape Corse peninsula, around the Cima di Gratera peak, and consists of what will be referred to hereafter as the Cima di Gratera ophiolitic nappe. Through an inferred tectonic contact called $\varphi_{1}$, this nappe overlies ductilely deformed units composed of continental basement rocks, meta-ophiolites and metasedimentary cover rocks (Pigno-Olivaccio and Morteda-Farinole units, Fig. 1) which recorded a HP-LT metamorphism (Lahondère, 1981, 1996; Vitale-Brovarone et al., 2013). The Cima di Gratera nappe consists of two superimposed units (Fig. 2): a lower serpentinite-peridotite unit (hereafter peridotite unit) and an upper metagabbro unit separated by a brittle/ductile flatlying contact referred to as $\varphi_{2}$.

According to Vitale-Brovarone et al. (2013), the highest metamorphic conditions recorded by meta-sedimentary rocks and continental units surrounding the Cima di Gratera nappe are temperatures between 414 and $471^{\circ} \mathrm{C}$ and pressures between 1.9 and $2.6 \mathrm{GPa}$, corresponding to blueschist to eclogite facies conditions. Comparable P-T conditions $\left(1.3 \mathrm{GPa}, 455 \pm 35^{\circ} \mathrm{C}\right)$ were estimated by Lahondère and Guerrot (1997) in similar units nearby the Cima di Gratera nappe. No accurate P-T conditions could be determined directly from the Cima di Gratera units. Following Deseta et al. (2014a and b) and despite the presence of faults between them, we suppose that the Cima di Gratera units suffered from P-T conditions comparable to those of the surrounding units, that is, blueschist to eclogite facies P-T conditions.

\subsubsection{The peridotite unit.}

The peridotite unit is composed of massive or foliated serpentinite embedding fresh to variably serpentinized peridotite lenses. Near the inferred $\varphi_{1}$ tectonic contact, the base of the unit consists of strongly foliated serpentinites whose foliation is severely folded or sheared by C-like surfaces. This intense basal deformation is interpreted as a consequence of the emplacement of the nappe over its substratum. Most serpentinites are distributed in the lower part of the peridotite unit and the degree of serpentinization generally decreases upwards from $\varphi_{1}$. Most peridotite masses are located near the $\varphi_{2}$ contact and have thicknesses between $20 \mathrm{~m}$ and $300 \mathrm{~m}$. The peridotite is massive and granoblastic. At locality 3 (Fig. 1), it is cut by a gabbro dyke. The peridotite is lherzolitic in composition, and is constituted by olivine, diopside, enstatite and minor plagioclase, Cr-spinel and magnetite (Deseta et al., 2014a). Pyroxenite was found near the contact $\varphi_{2}$ (locality 7), but the poor exposure conditions prevent to determine its actual extent and its nature (dyke, cumulate or sill). Recrystallization of diopside and enstatite to clinochlore and tremolite testifies to a greenschist facies metamorphism of the peridotite (Deseta et al., 2014a and b). On the other hand, and unlike the 
metagabbro of the overlying unit (see below), no mineralogical evidence for blueschist facies metamorphism could be found in the peridotite. That the peridotite itself does not contain any evidence for blueschist facies metamorphism most likely reflects the fact that its composition does not allow formation of minerals diagnostic of blueschist facies. Indeed (see our observations below and also Deseta et al., 2014a and b), peridotite-hosted pseudotachylyte veins contain omphacitic microlites indicating that the melt cooled and solidified under blueschist facies to eclogite facies conditions.

According to Deseta et al. (2014a), the greenschist facies metamorphism occurred during two events or successions of events, first before the formation of pseudotachylyte and then after it. The early metamorphic event or succession of events are tentatively related to hydrothermal alterations having occurred during ocean-continent hyperextension, during seafloor spreading at the ridge, or near the trench where the approaching plate bends. The late metamorphic event or succession of events are likely contemporaneous with slab exhumation or nappe emplacement processes.

In several localities, especially in the northern part of the study area, thin (about $15 \mathrm{~m}$ ) to thick (> $500 \mathrm{~m}$ ) lenses of strongly foliated meta-sedimentary rocks and metagabbros are found within the serpentinites, generally at short distances from the inferred basal contact $\varphi_{1}$ (Fig. 1). These lenses likely correspond to slices of the underlying units that were incorporated in the peridotite unit during nappe emplacement. The generally strong deformation (intense folding, shear bands offsetting foliation) of the rocks in the lenses and of the surrounding serpentinites is in favor of this interpretation.

\subsubsection{The metagabbro unit.}

The description of the metagabbro unit by Deseta et al. (2014a) is summarized below and is completed by our observations. The metagabbro unit is predominantly composed of an equant metagabbro. Only its basal part consists of a foliated metagabbro. The primary minerals of the equant metagabbro are plagioclase, diopside, minor olivine and rare ilmenite. Alteration of plagioclase into sericite and of olivine into serpentine, magnetite or iddingsite is common. The texture frequently changes from micro-gabbro to coarse-grained gabbro and locally to pegmatitic gabbro. A magmatic foliation is locally observed but could not be mapped because of exposure scarcity. The metagabbro is intruded by dolerite dykes (locality 12, Fig. 1). According to Deseta et al. (2014a), an early greenschist facies metamorphism of the gabbro is responsible for the partial or total replacement of diopside by actinolite, bastite or $\mathrm{Mg}$ hornblende. This early greenschist facies metamorphism is followed by a blueschist facies 
metamorphism as attested by the replacement of diopside, actinolite, $\mathrm{Mg}$-hornblende and plagioclase by glaucophane, barroisite, albite and epidote. A late greenschist facies metamorphism is evidenced by epidote, clinochlore and pumpellyite overprinting the blueschist facies minerals. Like for the peridotite unit, the early greenschist metamorphism of the gabbro is tentatively related to hydrothermal alteration having occurred during oceancontinent hyperextension, during seafloor spreading at the ridge, or near the trench through normal faulting of the bending plate (Deseta et al., 2014a and b). The late metamorphic event is considered to be contemporaneous with slab exhumation or nappe emplacement.

\subsubsection{The contact between the two units}

The contact $\varphi_{2}$ between the two units of the Cima di Gratera nappe, already described by Andersen et al. (2014), can be observed at several places (localities 6, 7, 8 and 9, Fig. 1). It consists in a flat-lying sharp fracture surface which undulates gently and which superimposes equant or foliated gabbro over peridotite or serpentinite. Weakly marked striations or corrugations trending $\mathrm{N}^{\circ} 5^{\circ} \mathrm{E}$ to $\mathrm{N} 120^{\circ} \mathrm{E}$ are preserved on the surface. The peridotite below the contact surface is intensely fractured and hosts abundant pseudotachylyte fault veins, most of which being parallel or slightly oblique to the surface (see description below). In the localities where the footwall consists of serpentinites, no pseudotachylyte could be found in these rocks.

Where the hanging-wall consists of equant metagabbro, up to $10 \mathrm{~cm}$ thick pseudotachylyte veins locally outline the base of the metagabbro unit. Where the hanging-wall consists of foliated metagabbro, the foliation is generally parallel to the contact but can also be oblique to it, forming angles of up to $35^{\circ}$. The thickness of the basal foliated metagabbro is between 20 $\mathrm{cm}$ and $30 \mathrm{~m}$. The mylonitic deformation progressively decreases in intensity when going upward, that is away from $\varphi_{2}$. The foliation bears a stretching lineation around $\mathrm{N} 120^{\circ} \mathrm{E}$. Polished hand-sample sections and thin sections perpendicular to the foliation and parallel to the lineation did not provide any consistent shear senses. Going upward and away from $\varphi_{2}$, minor shear zones cross-cut the equant metagabbro. Their thickness is about $15 \mathrm{~cm}$ but can locally reach $1.5 \mathrm{~m}$. They strike about N-S and dip between 10 and $40^{\circ}$ westward. Their foliation bears a weakly marked stretching lineation along $\mathrm{N} 80^{\circ} \mathrm{E}$. No consistent shear senses could be retrieved from hand sample sections or thin sections. The spatial as well as the chronological relationships between these minor shear zones and the main basal foliated zone could not be clarified. 


\section{Pseudotachylyte}

224

225

226

227

228

229

230

231

232

233

\subsection{Pseudotachylyte in the peridotite unit}

\subsubsection{General observations}

A summary of the description of the pseudotachylyte in the peridotite unit by Andersen et al. (2008, 2014), Andersen and Austrheim (2006), Austrheim and Andersen (2004) and Deseta et al. (2014a and b), completed by our observations, is given in the following. Pseudotachylyte veins in the peridotite are characterized by a positive relief and by an orange to yellowish color which contrasts with the rusty color of the host rock (Fig. 3). Two categories of pseudotachylyte veins are distinguished: fault veins and injection veins. In contrast with injection veins, fault veins can be followed along several tens of centimeters up to a few meters, have similar orientations, and their thickness is between a few millimeters and $30 \mathrm{~cm}$. Injection veins are rare, small (length $<10 \mathrm{~cm}$ ), and often cut by microfaults or cataclastic shear zones, rendering their recognition difficult. Most fault veins (about $90 \%$ ) do not occur as isolated occurrences, but are clustered in fault zones in which a large number of veins (commonly several tens) form anastomosed or tangled networks (Figs 3 to 6).

As demonstrated by hand sample polished sections or thin sections, the peridotite hosting the pseudotachylyte veins, whatever these are isolated or forming networks, is cataclastic to varying extents. Where cataclasis is important, the granoblastic texture cannot be recognized any more. Where cataclasis is moderate, olivine crystals, yet fractured, can be distinguished.

In the peridotite unit, the fresh (i.e., not serpentinized) peridotite always contains pseudotachylyte. Conversely, the massive serpentinite does not contain any pseudotachylyte. In the vicinity of localities 4 and 12 (Fig. 1), some fault or injection veins can be recognized in serpentinite but, in these occurrences, serpentinization affects both the host rock and the veins, and clearly post-dates pseudotachylyte formation.

As already reported by Andersen et al. (2014), unlike all pseudotachylyte occurrences described in non-ductilely deformed host rocks and particularly in other ultramafic rocks (Obata and Karato, 1995; Piccardo et al., 2007, 2010; Souquière and Fabbri, 2010; Ueda et al., 2008), the peridotite fault veins form complex anastomosed or tangled networks inside which no general relative chronology between veins can be established. Indeed, cross-cutting relationships between a limited number (up to 3) veins are often observed at the outcrop scale 
and also at the thin section scale, but remain insufficient with respect to the large number of veins to allow a complete chronology of a single fault zone to be reconstructed.

Another difference between the Cima di Gratera peridotite pseudotachylyte and most occurrences from elsewhere lies in the scarcity of sharp and planar fault surfaces adjacent to fault veins. Indeed, since the pioneering work of Sibson (1975), it has been recognized that fault veins are always flanked, on one side or on both sides, by sharp, commonly planar, slip surfaces whose length is between one and several meters or tens of meters (e.g., Allen, 2005; Di Toro and Pennacchioni, 2005; Grocott, 1981; McNulty, 1995; Swanson, 1988; Wenk et al., 2000; Zechmeister et al., 2007). In the case of the Cima di Gratera peridotite unit, such meterscale slip surfaces are rare. This seems to be also the case for the Lanzo peridotite pseudotachylyte (Piccardo et al., 2007, 2010).

\subsubsection{Geometry and kinematics of pseudotachylyte-bearing fault zones}

As reported by Andersen and Austrheim (2006), two types of pseudotachylyte fault veinbearing zones can be distinguished in the peridotite unit: flat-lying fault zones in the upper part of the unit (near $\varphi_{2}$ ), and steeply-dipping fault zones in the middle or lower part of the unit (Fig. 2). Isolated fault veins also follow this geometry: flat-lying veins in the upper part of the peridotite unit, steeply dipping ones in the lower part. To determine the sense of displacement (seismic slip) associated with pseudotachylyte fault veins and given the fact that the fault veins or associated cataclastic surfaces lack displacement direction indicators such as striations, field-oriented hand samples were cut along vertical planes striking N-S, NE-SW, EW and NW-SE. For all samples, the most coherent sense of displacement criteria are observed along NW-SE surfaces and to a lesser extent along E-W surfaces. This indicates that the NWSE direction is likely the displacement direction.

\section{Flat-lying pseudotachylyte-bearing fault zones}

Two main flat-lying fault zones are found in the peridotite unit (Fig. 2): the first one is located immediately beneath the $\varphi_{2}$ contact where it can be followed almost continuously (localities 4 to 12, Fig. 1); the second one is located in the median part of the unit (localities 1 and 3, Fig. 1). The thickness of the fault zone beneath $\varphi_{2}$ varies between 25 and $250 \mathrm{~m}$, while that at localities 1 and 3 is about $15 \mathrm{~m}$. In the fault zone beneath $\varphi_{2}$, fault veins are parallel or slightly oblique to $\varphi_{2}$ and their density unambiguously increases upwards when getting closer to $\varphi_{2}$. The parallelism between veins also tends to increase when getting closer to the contact. Examination of outcrops, polished hand sample sections and thin sections reveals numerous 
cross-cutting relationships between fault veins. As stated above, because of the complexity of the relationships, it is not possible to establish a unique and complete chronology of seismic ruptures in the flat-lying fault zones. The only clear relationship observed at all localities consists in early gently to moderately $\left(5 \sim 20^{\circ}\right)$ dipping fault veins offset by late flat-lying to gently dipping $\left(0 \sim 10^{\circ}\right)$ fault veins. Early veins often show blurred boundaries. Conversely, late veins have sharp boundaries, and are frequently thinner than early veins. Cataclasite is always associated with the early veins but is seldom observed along the late veins. For the two fault zones (Figs 3 and 4), the sense of displacement associated with late veins is top-tothe-northwest or top-to-the-west. The sense of displacement associated with the early veins remains undetermined. Top-to-the-northwest or top-to-the-west displacement senses are obtained for isolated flat-lying fault veins scattered in the peridotite unit.

\section{Steeply dipping pseudotachylyte-bearing fault zones}

In addition to isolated steeply dipping veins, three steeply dipping pseudotachylyte-bearing fault zones are observed (localities 1, 3 and 5, Fig. 1). They consist of anastomosed networks of fault veins hosted by cataclastic peridotite. Their thickness varies between $30 \mathrm{~cm}$ and $1 \mathrm{~m}$. The two first zones strike $\mathrm{N} 20^{\circ} \mathrm{E}$ to $\mathrm{N} 40^{\circ} \mathrm{E}$ and dip $55^{\circ}$ eastwards. The third zone (locality 5) strikes around $\mathrm{N} 80-\mathrm{N} 100^{\circ} \mathrm{E}$ and dips $55^{\circ}$ northwards. The two first fault zones display a clear zonation with cataclastic peridotite predominating in the hanging-wall side and fault veins predominating in the footwall side. This asymmetrical zonation is reminiscent of pseudotachylyte described in different geological settings and host rocks (Fabbri et al., 2000). Kinematic indicators suggest that the sense of displacement during formation of the steeply fault veins was a reverse one, that is a top-to-the-northwest one (Figs 5 and 6). Flat-lying or gently-dipping $\left(0 \sim 10^{\circ}\right)$ fault surfaces, most of them being coated by pseudotachylyte, crosscut the steeply dipping fault veins of the three steeply-dipping fault zones. Kinematic indicators associated with these late flat-lying faults indicate a top-to-the-west or top-to-thenorthwest sense of displacement. The same cross-cutting relationships and kinematics are obtained for the isolated steeply dipping fault veins scattered in the peridotite unit: steeply dipping fault veins are cross-cut by flat-lying veins, but both types are characterized by a topto-the-west or top-to-the-northwest sense of displacement.

\section{Relative dating of flat-lying and steeply-dipping fault zones.}

Both flat-lying and steeply dipping fault zones were the sites of repeated seismic ruptures, as attested by multiple generations of pseudotachylyte veins. Given the complexity of crosscutting relationships, it is difficult to establish a chronology of seismic ruptures within each 
fault zone and also between fault zones. It is particularly impossible to establish a chronology between flat-lying and steeply-dipping fault zones. However, the latest recorded seismic ruptures are those corresponding to flat-lying or gently dipping, thin $(<5 \mathrm{~mm})$ pseudotachylyte veins displacing all pre-existing veins in either type of fault zones. These veins are rarely associated with cataclasite, hence their sharp boundaries. The ubiquity of these most recent veins suggests that activity of the flat-lying fault zones, especially that beneath $\varphi_{2}$ (which contains a lot of such late veins), lasted for a longer time than that of the steeply dipping fault zones.

\subsubsection{Pseudotachylyte in the peridotite unit: microscopic observations}

The peridotite pseudotachylyte fault veins are of two types: microlitic and annealed (Fig. 7). Unlike the annealed type which is found only in the flat-lying fault zone beneath $\varphi_{2}$, the microlitic type is found in all vein types, whatever their relative chronology (early as well as late veins).

The microlitic type is characterized by abundant microlites embedded in a brownish amorphous or crypto-crystalline matrix (Fig. 7A, B and C). Microlites have dendritic shapes, with sizes between $1 \mu \mathrm{m}$ and $120 \mu \mathrm{m}$. They commonly draw a zonation in veins, with no or very small microlites at the vein margins and large microlites in the median part of the veins. Such zonations likely reflect quenching at the vein margins. Microlites observed in the thickest veins ( $>5 \mathrm{~cm}$ ) have sizes up to $1.5 \mathrm{~mm}$ and display spinifex textures. Microlites consist mostly of olivine. Diopside and enstatite are less common. 'Survivor' clasts, about $10 \%$ in volume, consist mostly of monocrystalline olivine and minor pyroxene. Some polycrystalline clasts consist of olivine and pyroxene. Clasts of pseudotachylyte are also observed, especially in the flat-lying fault veins beneath $\varphi_{2}$. The largest clasts are frequently elongated and parallel to the vein walls. Flow folds are common in injection veins, especially at their root. Although most pseudotachylyte vein boundaries are sharp, some are diffuse and show a progressive transition from pseudotachylyte to cataclasites (see below). Such diffuse boundaries are found on one side of the vein wall only, the other showing a sharp transition from pseudotachylyte to host rock. Some microlitic veins, especially flat-lying ones located near the boundary between intact peridotite and surrounding serpentinite, are serpentinized, but the textures, including microlites and clasts, are preserved, showing that serpentinization post-dates melting. 
The annealed pseudotachylyte type (Fig. 7D and E) was observed only in the flat-lying fault zone of locality 4 . The annealed type fault veins have thicknesses between 0.8 and $1.5 \mathrm{~cm}$. They are crossed by numerous cooling cracks perpendicular to the vein walls. The matrix consists of entirely recrystallized olivine with a granoblastic annealed texture. The crystal size is homogeneous, except at the margins, with a mean size of $c a .10 \mu \mathrm{m}$. Crystal junctions are triple and typically define $120^{\circ}$ angles. Chilled margins are thin $(<0.5 \mathrm{~mm}$ thick). Survivor clasts are rare ( $<5 \%$ in volume) and consist of monocrystalline or polycrystalline olivine. Injection veins are not entirely recrystallized, their central part showing a microlitic texture. This suggests that the annealed-type veins are originally microlitic type veins that were subsequently recrystallized.

An important characteristic of the peridotite fault veins, especially the early ones, is that they are frequently flanked, on either side, by cataclastic peridotite (Figs 8 and 9). Cataclasite can be found in association with late veins from flat-lying fault zones, but never with late veins from the steeply dipping fault zones. Where cataclasite is present, a progressive evolution from proto-cataclasite to cataclasite and to ultra-cataclasite can be observed. The cataclasite usually remains on the same side of the fault vein, but can also shift to the opposite side, through a progressive decrease of the cataclastic domain on one side and a correlative increase on the other side.

The kinematics determined from the observation of outcrops or of polished hand sample sections (top-to-the-west or top-to-the-northwest displacement senses) are also observed at the thin section scale. Figure 10 shows examples of criteria of displacement senses associated with early and late veins of steeply dipping fault zones and with late veins from flat-lying fault zones.

\subsection{Pseudotachylyte in the metagabbro unit}

In the metagabbro unit, pseudotachylyte veins are common in the mylonitic sole and abundant just above it (in the equant metagabbro). Their density decreases upwards. At a distance larger than $300 \mathrm{~m}$ above $\varphi_{2}$, no more veins can be found. As already noted by Andersen and Austrheim (2006), within the mylonitized sole, some veins were formed before mylonitization and others were formed after it (Fig. 11).

\subsubsection{Pre-mylonitization pseudotachylyte in the foliated sole}


In the foliated metagabbro, dark bluish to blackish fault veins are parallel or slightly oblique to the foliation. Their thickness is less than $5 \mathrm{~mm}$. Because of mylonitization-related stretching and pinch-and-swell, they show a poor lateral continuity and cannot be followed over more than a few centimeters. In some instances, they are flanked by injection veins which are offset by millimeter-thick shear zones parallel to the foliation. No clear kinematics is associated with the pre-mylonitization veins.

Most textures typical of pseudotachylyte are obliterated by the penetrative foliation (Fig. 12). Flow structures, chilled margins and microlites are no longer recognizable. Newly formed minerals are aligned in the foliation and consist of glaucophane, albite, epidote and ilmenite. Survivor clasts, mostly plagioclases, are elongated in the foliation and are flanked with pressure shadows. They are smaller (maximum $50 \mu \mathrm{m}, 30 \mu \mathrm{m}$ on average) than the clasts in the non-mylonitized veins.

\subsubsection{Post-mylonitization pseudotachylyte in the foliated sole}

Post-mylonitization fault veins are greenish to greyish and are not foliated (Fig. 11). Most fault veins are parallel or nearly parallel to the foliation. The parallelism between most of the fault veins and the foliation likely reflects a mechanical influence of the foliation on the seismic rupture propagation and hence on the resulting attitude of the veins. Postmylonitization fault veins as well as injection veins are also found to cross-cut premylonitization veins. No clear kinematics can be attributed to the post-mylonitization pseudotachylyte veins.

Post-mylonitization fault veins are usually less than $5 \mathrm{~mm}$ thick, but can reach $10 \mathrm{~mm}$. Clasts consist mostly of plagioclase, with minor tremolite or pyroxene. The largest clasts, especially the pyroxene ones, show embayments. The matrix is cryptocrystalline or glassy, and includes microlites of albite and glaucophane. The length of the microlites is between 10 and $20 \mu \mathrm{m}$, but decreases to less than $5 \mu \mathrm{m}$ near the vein boundaries (chilled margins). Flow folds are abundant and are defined by alternating layers of microlites of different sizes. Injection veins are rare. They include less clasts than the fault veins do. The cryptocrystalline or glassy matrix contains microlites which are slightly larger $(40 \mu \mathrm{m})$ than in the fault veins. The mineralogical nature of clasts or microlites is the same as in the fault veins.

\subsubsection{Pseudotachylyte in the equant metagabbro above the foliated sole}


The appearance of pseudotachylyte veins in the equant metagabbro is similar to that of postmylonitization veins in the foliated sole. In particular, cross-cutting relationships between veins are common and indicate polyphase seismic rupturing. A notable difference is that lenses of pseudotachylyte-supported breccias are observed in equant metagabbro but not in the foliated sole. These lenses are up to $15 \mathrm{~cm}$ thick and include rounded fragments of equant metagabbro and foliated metagabbro. They are interpreted as local accumulations in so-called dilational or releasing bends located along slipping surfaces (Sibson, 1986). Another difference is that the fault vein attitudes in the equant metagabbro are scattered. Particularly, veins parallel or slightly oblique to $\varphi_{2}$ are scarce.

The metagabbro pseudotachylyte matrix is glassy or crypto-crystalline. Using X-ray diffraction synchrotron, Deseta et al. (2014b) produced Laue patterns without diffraction points, showing unambiguously the presence of glass in the matrix. Survivor clasts are well rounded and show the same mineralogical nature as in post-mylonitization veins. Feldspar clasts are numerous and small whereas pyroxene and olivine clasts are scarce and large. Microlites consist mainly of fibrous or acicular, rarely spherulitic, pyroxene. Deseta et al. (2014b) report the presence of blueschist facies microlites, namely Al-rich omphacite, high$\mathrm{Fe}$ anorthite and accessory ilmenite. A few thin sections show different microlite assemblages, suggesting different stages of vein formation. Some veins contain omphacite but no tremolite or actinolite, some others contain tremolite or actinolite but no omphacite. Omphacite-bearing veins likely formed under high-pressure conditions while amphibolebearing veins formed in shallower conditions (greenschist facies). Unfortunately, such observations are too scarce to allow a reliable sorting of the equant metagabbro veins.

Pseudotachylyte veins in the equant metagabbro and post-mylonitization veins in the foliated sole can be considered as contemporaneous. However, a part of the veins in the equant metagabbro, especially those cut by other veins, could be older and could have been formed coevally with the pre-mylonitization veins. Only absolute dating of the veins could help clarify the relationships between post-mylonitization veins in the foliated metagabbro and veins in the non-foliated metagabbro.

\section{Discussion: Analysis of the seismic ruptures fossilized in the study area and comparison with present-day subduction zone seismology}


The $\varphi_{2}$ contact is interpreted as an ancient deformed Moho interface by Andersen et al. (2008, 2014). Alternatively, $\varphi_{2}$ can be interpreted as an ancient low-angle detachment fault or shear zone dating back to the initial stretching of the continental lithosphere before formation of the Piemonte-Liguria basin (Meresse et al., 2012), following the model of Manatschal and Müntener (2009). It can also be interpreted as an ancient low-angle detachment fault located at or near the accretion ridge of the Piemonte-Liguria basin (Vitale-Brovarone et al., 2014) following the models of Tucholke and Lin (1994) or Cannat et al. (2009). If $\varphi_{2}$ is an ancient detachment (at the ridge or in the ocean-continent transition), it may not coincide with the Moho interface. The supposed detachment could have been reactivated during plate convergence or during subsequent collision and nappe emplacement. Whatever its origin, the detachment should have been localized beneath the bulging sides of a gabbro diapiric pluton emplaced in the uppermost mantle, to account for the gabbro-over-peridotite succession observed in the study area. Lastly, the two scenarios (reactivated Moho or detachment in the uppermost mantle) are not contradictory. Both involve a low-angle shear zone in the upper part of the lithosphere.

The ductile deformation of the metagabbro sole may result from one or several of the following settings: (1) normal shear along a crustal-scale detachment following continental lithosphere breakup (e.g., Meresse et al., 2012; Vitale-Brovarone et al., 2014), (2) normal shear along an axial detachment fault near the spreading ridge of the Piemonte-Liguria basin, (3) reverse shear along the crust-mantle boundary (Moho) of the subducting slab. The lack of kinematic indicators in the metagabbro sole prevents distinguishing stages (1) or (2) (normal sense of shear) from stage (3) (reverse sense of shear).

Whatever the setting, the ductile deformation was achieved at a place where the ambient temperature was higher than the brittle/ductile transition temperature of gabbro. Since the plagioclase modal content in the metagabbro is about $50 \%$, a minimum estimate of the brittle/ductile transition temperature is $c a .550^{\circ} \mathrm{C}$ (e.g., Molli, 1994; Hansen et al., 2013). Given the abundance of pyroxenes (about $35 \%$ modal content), the actual transition temperature of the metagabbro is likely higher. The maximum metamorphic temperatures in the study area are $414-471^{\circ} \mathrm{C}$ (Vitale-Brovarone et al., 2013), that is less than $550^{\circ} \mathrm{C}$. This could rule out the possibility of a ductile deformation in the subducting slab. However, by admitting that the metagabbro underwent some hydrothermal alteration (as can be expected if $\varphi_{2}$ is a reactivated detachment), its brittle/ductile transition temperature would have been lower (ca. $300^{\circ} \mathrm{C}$, Stünitz, 1993), thus permitting ductile deformation. 
Calling upon ductile deformation of the metagabbro sole along a detachment in the oceancontinent transition or at the mid-oceanic ridge (and hence generation of pre-mylonitization pseudotachylyte at the same place) requires that these early structures will then be transported until the subduction zone at intermediate depths where they will be overprinted by (postmylonitization) pseudotachylyte veins. In particular, it means that (pre-mylonitization) pseudotachylyte veins formed away (200 600 km away according to Guerrera et al., 1993; Stampfli et al., 1998; Rosenbaum et al., 2002; Marroni and Pandolfi, 2007; Turco et al., 2012) from the subduction zone will be overprinted by (post-mylonitization) pseudotachylyte veins formed at depth $(>60 \mathrm{~km})$ in a subduction zone. Though not impossible, such a coincidence does not seem very plausible.

Figure 13 suggests a simpler scenario in which both pseudotachylyte and mylonite are formed in the subducting slab at shallow to intermediate depths. Pre-mylonitization pseudotachylyte is formed at depths shallower than the gabbro brittle/ductile transition isotherm. It can be formed near the trench, along the Moho (Fig. 13A), following a scenario proposed by Singh et al. $(2008,2011)$ to account for the location of the hypocenters and rupture propagation geometries of the 2004 Sumatra and 2010 Pagai events. A similar possibility of seismic ruptures inside the oceanic crust of the subducting Philippine Sea plate beneath SW Japan was also suggested by Tsuji et al. (2009, 2013). Pre-mylonitization pseudotachylyte can alternatively be formed deeper, before being subsequently mylonitized when passing through the brittle/ductile transition isotherm. Continuing shear along the crust-mantle boundary would result in $\varphi_{2}$-parallel seismic ruptures in the brittle peridotite and in $\varphi_{2}$-parallel foliation in the metagabbro sole (Fig. 13B). That post-mylonitization pseudotachylyte cross-cuts the foliated metagabbro suggests oscillations of the gabbro brittle/ductile transition isotherm. Such oscillations are possible. Indeed, numerical simulations of long-term equilibrium state of the subduction interplate show that the brittle/ductile transition is almost parallel to the crustmantle boundary of the subducting slab (Arcay, 2012). An alternative view is that postmylonitization pseudotachylyte veins, especially those perpendicular or highly oblique to the foliation, result from seismic ruptures having nucleated in the underlying mantle and having propagated upwards across the ductile metagabbro (Fig. 13D).

\subsection{Formation of peridotite pseudotachylyte}

\subsubsection{Weakening mechanisms facilitating seismic ruptures at intermediate depths}


Intermediate-depth seismicity as well as deep-focus seismicity are puzzling. Indeed, given the high stresses expected at depths $>60 \mathrm{~km}$, brittle fracturing or frictional sliding along preexisting fractures require unrealistic rock strengths or over-pressurized pore fluids which could reduce stresses. Yet earthquakes occur. To solve this paradox, three mechanisms have been proposed (Green and Houston, 1995; Hacker et al., 2003; Frohlich, 2006; Houston, 2015): dehydration embrittlement, ductile shear instability and transformational faulting.

Transformational faulting calls for the formation of anticracks during phase transformation of olivine to denser phases such as $\beta$ - or $\gamma$-spinel (Green and Burnley, 1989; Kirby et al., 1991; Wiens et al., 1993; Schubnel et al., 2013). The applicability of transformational faulting as a possible mechanism accounting for intermediate-depth seismicity in the subducting oceanic lithosphere is questionable (e.g., Hacker et al., 2003) because (1) the expected reactions are too slow compared with earthquake timescales, (2) olivine remains stable at the considered depths, and (3) the metamorphism of basalts or gabbros does not involve the polymorphic reactions required in transformational faulting processes.

Dehydration embrittlement is based on a pore fluid pressure increase leading to fracture formation or reactivation by decrease of the otherwise high normal stresses. The pore fluid pressure increase would result from fluid accumulations following dehydration reactions of hydrated minerals. Seismological observations and data modeling, laboratory experiments, field observations and thermal and thermodynamic computations have pointed out possible links between intermediate-depth seismicity and dehydration reactions affecting hydrated rocks or minerals of the subducting slab such as basalt, gabbro, chlorite, antigorite, talc or brucite (Raleigh and Paterson, 1965; Rutter and Brodie, 1988; Green and Burnley, 1989; Green et al., 1990; Green and Houston, 1995; Kirby, 1995; Seno and Yamanaka, 1996; Davis, 1999; Peacock, 2001; Seno et al., 2001; Dobson et al., 2002; Wang, 2002; Hacker et al., 2003; Preston et al., 2003; Yamazaki and Seno, 2003; Jung et al., 2004; Wang et al., 2004; Brudzinski et al., 2007; Hirose and Bystricky, 2007; Rondenay et al., 2008; Hasegawa et al., 2009; Nakajima et al., 2009; Angiboust et al., 2012; Abers et al., 2013; Nakajima et al., 2013; Houston, 2015). A strong argument justifying the link between intermediate-depth seismicity and dehydration reactions in the subducting slab lies in overlaps between predicted dehydration reaction isotherms and location of hypocenters (e.g., Peacock, 2001 or Hacker et al., 2003). Regarding the upper Wadati-Benioff seismic sub-zone, the source of fluids would lie in dehydration reactions transforming basalts or gabbros into blueschist or eclogite-facies rocks (Hacker et al., 2003; Preston et al., 2003; Yamazaki and Seno, 2003; Kita et al., 2006; Nakajima et al., 2009). Regarding the lower Wadati-Benioff sub-zone, the source of fluids 
should be searched for in dehydration reactions of chlorite or antigorite since these two minerals are thought to be present in the mantle of subducting slabs (Seno and Yamanaka, 1996; Peacock, 2001; Seno et al., 2001; Hacker et al., 2003). Dehydration reactions have been invoked to account for secondary olivine crystallization along natural fault zones in ophiolitic rocks from the Voltri complex in Italy (Hoogerduijn-Strating and Vissers, 1991; Scambelluri et al., 1991). According to Hoogerduijn-Strating and Vissers (1991), fluid overpressures would nearly reach lithostatic values.

Ductile instability, also called thermal runaway or thermal shear instability, postulates that the temperature-dependent viscosity of a highly localized, ideally fine-grained, creeping ductile shear zone is progressively reduced by the heat provided by continuing creep (Ogawa, 1987; Kameyama et al., 1999; Braeck and Podladchikov, 2007; Kelemen and Hirth, 2007). This positive feedback between continuing creep and temperature rising can eventually lead to seismic failure. This mechanism was evoked in the case of the $1994 M_{w} 8.2$ Bolivian deepfocus earthquake (depth $=637 \mathrm{~km}$ ) by Kanamori et al. (1998), who further suggested that failure could have led to melting along the newly nucleated fault surface. Indeed, these authors calculated that, for a starting shear zone thinner than $1 \mathrm{~cm}$, temperature elevation in the shear zone would exceed $10,000^{\circ} \mathrm{C}$, which is far higher than melting temperature of any rock. Source parameter scaling and energy budget of clusters of intermediate-depth (140-160 km) $M_{w}$ 4-5 earthquakes beneath northern Colombia led Prieto et al. (2013) to suggest that propagation of these ruptures was caused by a thermal runaway mechanism. A similar mechanism was suggested by Wiens and Snider (2001) to account for deep (550-600 km) earthquakes in the Tonga slab. From the analysis of closely associated mylonitic zones and pseudotachylyte across a gabbro metamorphosed under high- to ultrahigh-pressure conditions in Norway, John et al. (2009) suggested that co-seismic melting was contemporaneous with ductile shear and is the result of a self-localizing thermal runaway process along the shear zones. Another example of possible thermal runway frozen in the geological record is provided by Andersen et al. (2008, 2014) and Deseta et al. (2014a), as is discussed below.

\subsubsection{Did dehydration embrittlement facilitate seismic failure in the peridotite unit?}

According to Deseta et al. (2014a), the metagabbro pseudotachylyte was formed under eclogite facies P-T conditions (presence of omphacite microlites in the matrix) before being retrogressed under blueschist facies P-T conditions (presence of glaucophane microlites). These authors estimate that the P-T conditions of crystallization of glaucophane and omphacite microlites in the metagabbro pseudotachylyte are between 430 and $550^{\circ} \mathrm{C}$ and 1.8 
$\mathrm{GPa}$ and 2.6 GPa, corresponding to blueschist to eclogite facies conditions. These values are close to those obtained in the units around the Cima di Gratera nappe by Vitale-Brovarone et al. (2013) which are $414-471^{\circ} \mathrm{C}$ and $1.9-2.6 \mathrm{GPa}$. With a mean rock density of $3000 \mathrm{~kg} / \mathrm{m}^{3}$ and assuming a lithostatic equilibrium, the pressure range corresponds to depths between 60 and $90 \mathrm{~km}$. P-T conditions in the peridotite pseudotachylyte cannot be ascertained. Indeed, the microlites (diopside, olivine, enstatite and clinochlore) that crystallized during cooling of the melt do not bring any constraints on the pressure conditions during pseudotachylyte formation. However, if considering the peridotite unit as attached to the metagabbro unit during subduction, then the same metamorphic conditions should apply to both units. In other words, it can be assumed that pseudotachylyte in the peridotite unit formed under blueschist to lawsonite-eclogite facies conditions, as suggested by Deseta et al. (2014a).

As mentioned above, antigorite, which is common in the serpentinites or serpentinized peridotites of the Cima di Gratera nappe, is a candidate to account for dehydration embrittlement and subsequent seismicity in subducting slabs. The P-T conditions for antigorite dehydration are known from experiments and are between 550 and $720^{\circ} \mathrm{C}$ for pressures between 1 and 3 GPa (Ulmer and Trommsdorff, 1995; Wunder and Schreyer, 1997; Dobson et al., 2002; Perrillat et al., 2005; Hilairet et al., 2006; Padron-Navarta et al., 2010). The peak temperatures supposedly recorded by the peridotite pseudotachylyte $\left(430-550^{\circ} \mathrm{C}\right.$, see above) or in the surrounding units $\left(414-471^{\circ} \mathrm{C}\right.$, Vitale-Brovarone et al., 2013) are lower than the temperatures required for dehydration of antigorite-bearing serpentinite. This temperature difference renders dehydration of the mantle unit antigorite unlikely. In addition to these temperature issues, no optical microscope or SEM observations of secondary olivine newly crystallized at the expense of primary antigorite, such as the assemblages described by Hoogerduijn-Strating and Vissers (1991) or by Scambelluri et al. (1991), could be found in the pseudotachylyte veins or in their vicinity, confirming that antigorite dehydration did not occur in the peridotite. Andersen et al. (2014) and Deseta et al. (2014b) confirm that they did not observe secondary anhydrous minerals resulting from the dehydration of serpentine, talc, clinochlore or amphibole in the Cima di Gratera metagabbros or peridotites. For the time being, we consider that dehydration embrittlement was not an operative mechanism during seismic failure in the peridotite unit.

\subsubsection{Did self-localizing thermal runaway facilitate seismic failure in the peridotite unit?}

Deseta et al. (2014a) report thin-section scale (20 $\mathrm{mm}$ to $<100 \mu \mathrm{m}$ range) ductile (plastic) deformation structures inside or along pseudotachylyte fault veins. These structures include 
(1) elongated wallrock clasts in gabbro-hosted pseudotachylyte veins, (2) crystal plastic deformation of the host metagabbro along the boundaries of pseudotachylyte veins, (3) grain boundary alignment in prolate and lozenge-shaped grains suggesting grain boundary migration in some peridotite-hosted pseudotachylyte veins, and (4) plastic ribbons in gabbroor peridotite-hosted ultracataclasites. Additionally, by analyzing dislocation slip systems in olivine from peridotite wall rock or from clasts in the pseudotachylyte with the help of electron backscatter diffraction, Andersen et al. (2014) and Deseta et al (2014b) suggested that ductile deformation preceded pseudotachylyte formation. Based on these microscale ductile precursors to seismic faulting found along pseudotachylyte fault veins in the Cima di Gratera peridotites and gabbros, Andersen et al. (2014) and Deseta et al. (2014a and b) suggested that seismic ruptures were facilitated or triggered by a self-localizing thermal runaway process.

The possible activity of this process in the basal foliated metagabbro sole cannot be demonstrated nor discarded. Indeed, the parallelism between (post-mylonitization) pseudotachylyte fault veins and the foliation of the basal metagabbro probably results from the influence of the pre-existing foliation on the propagation of the seismic rupture, as often invoked in other settings (e.g., Grocott, 1981; Swanson, 1988; Allen, 2005; Zechmeister et al., 2007). More generally, pseudotachylyte veins preserved inside mylonitic zones are quite common (e.g., Sibson, 1980; Passchier, 1982), and their formation, although influenced or guided by the pre-existing planar heterogeneity as stated above, does not necessarily depend on a precursory softening shortly before seismic rupturing, as required in the ductile instability mechanism.

Unlike Deseta et al. (2014a and b), we did not observe any ductile shear zones along the peridotite fault veins, despite a large number of thin sections prepared with samples from the peridotite unit. We rather observe a quasi-ubiquitous association of pseudotachylyte veins with cataclastic peridotite. Consequently, ductile instability does not appear as a predominant mechanism associated with seismic ruptures in the peridotite unit of the study area.

\subsubsection{Did cataclasis facilitate seismic failure in the peridotite unit?}

Peridotite-hosted pseudotachylyte fault veins are almost always flanked by cataclasite (Figs 8, 9 and 10). Cataclasis may predate or postdate frictional melting, as shown by cataclasite zones crossed by pseudotachylyte veins or by fragments of pseudotachylyte included in cataclasites. Similar pseudotachylyte-cataclasite associations were reported from natural occurrences 
1995; Curewitz and Karson, 1999; Fabbri et al., 2000; Rowe et al., 2005; Di Toro and Pennacchioni, 2004, 2005; Piccardo et al., 2007, 2010) and also from rock friction experiments (Spray, 1995; Del Gaudio et al., 2009; Hirose et al., 2012). Swanson (1992) considered the cataclasite as the result of the propagating seismic rupture front, frictional melting occurring during seismic slip behind the front. Curewitz and Karson (1999) proposed that cataclasite results from slip surface leveling by asperity grinding and abrasion. Since a cataclastic peridotite is obviously mechanically weaker than an intact peridotite, one can expect cataclasis to be a precursory weakening mechanism facilitating ensuing seismic rupture. Unlike dehydration-derived over-pressurized fluids, cataclasis per se does not contribute to counterbalance the high stresses expected at depths $>60 \mathrm{~km}$. Though this mechanism does not bring any answer to the enigma of earthquakes at great depths, it however provides a plausible way to mechanically weaken strong rocks.

\subsection{Co-seismic displacement kinematics frozen in the peridotite unit compared with present-} day Wadati-Benioff zone earthquakes

Figure 14 shows a comparison between co-seismic kinematics frozen in the peridotite unit and the intermediate-depth seismicity of the Pacific plate presently subducting beneath NE Japan. The Pacific plate is taken as representative of a cold slab. It is also a slab for which high-resolution seismological data are available. The choice of the intermediate-depth seismicity is justified by the fact that the peridotite-hosted pseudotachylyte were formed at depths between 60 and $90 \mathrm{~km}$, as suggested by the metamorphic pressure conditions in the overlying metagabbro unit, supposed attached to the underlying peridotite unit. Since the kinematics of gabbro-hosted pseudotachylyte are undetermined, the discussion will be largely based on peridotite-hosted occurrences, with the assumption of an Alpine-type east-dipping subduction (Section 2.1).

Given the large $\left(55^{\circ}\right)$ angle between flat-lying fault zones and the earliest veins of the steeplydipping fault zones in the peridotite unit, no unique stress tensor can account for simultaneous slip along the two zones, suggesting that when one fault zone was active, the other was not active. The pervasive intermingling between flat-lying and steeply-dipping veins suggests that the two types of fault zones were active alternatively and under oscillating stress conditions. Such changing stress conditions could result from the near-surface interplate seismic cycle and periodic unlocking of the shallow plate interface during large earthquakes as suggested by Astiz et al. (1988). 
Several authors showed that in the case of cold slabs, the upper surface of the intermediatedepth Wadati-Benioff zone is characterized by a so-called downdip compression, meaning that $\mathrm{P}$ axes of earthquakes are parallel or almost parallel $\left(<30^{\circ}\right)$ to the dipping direction of the subducting slab (Isacks and Molnar, 1971; Apperson and Frohlich, 1987; Green and Houston, 1995; Kao and Liu, 1995; Igarashi et al., 2001; Chen et al., 2004). The reverse kinematics observed in the steeply-dipping fault zones agree with this configuration. Indeed, in slab coordinates, a $55^{\circ}$ dipping earthquake fault plane would have a 'favorably' oriented $\mathrm{P}$ axis at 30 to $45^{\circ}$ to the fault plane, that is, at $10^{\circ}$ to $25^{\circ}$ to the slab upper surface (taken parallel to $\varphi_{2}$ ).

Refining the comparison with cold subducting plates, a series of events having occurred in the early 2000s in the Pacific plate beneath NE Japan gives some insights on the geometry and sense of slip of the Corsican paleo-ruptures (Fig. 14B and C). First, the November 3, 2002, $M$ 6.1 earthquake which occurred along the upper Wadati-Benioff plane beneath NE Japan (Okada and Hasegawa, 2003) can constitute an analog to seismic ruptures along flat-lying fault zones in the peridotite unit or in the base of the metagabbro unit, on either side of $\varphi_{2}$. Indeed, the actual fault plane of this event was parallel to the alignment defining the upper Wadati-Benioff plane (i.e., parallel to the crust-mantle boundary) and the sense of slip was reverse. The analogy is somewhat limited by the shallow focal depth $(38 \mathrm{~km})$ of this event (Hasegawa et al., 2007), meaning that it is not strictly speaking an intermediate-depth earthquake. Second, the May 26, 2003 M 7.1 earthquake that occurred in the Pacific plate (focal depth $68 \mathrm{~km}$ ) can be an analog to seismic ruptures along steeply-dipping fault zones in the peridotite unit. This event was located near the upper Wadati-Benioff plane, close to the crust-mantle boundary (Okada and Hasegawa, 2003). Its hypocenter was $50 \mathrm{~km}$ away from the November 3, 2002 event. Okada and Hasegawa (2003) further showed that aftershocks were distributed along the steeply-dipping nodal plane, straddling both the oceanic crust and the uppermost mantle. Sense of slip was reverse. The angle between the fault plane and the crust-mantle boundary is $50^{\circ}$ (Hasegawa et al., 2007), a value quite comparable to the $55^{\circ}$ angle between the flat-lying and the steeply dipping fault zones observed in the peridotite unit. The analogy between the Pacific slab upper Wadati-Benioff seismic events and the Corsican configuration is depicted on Fig. 14. Slab-boundary parallel seismic ruptures would be analogous of the November 3, 2002 earthquake off NE Japan and, more generally, could be deeper equivalents of the low-angle thrust fault ("LT") type events of Igarashi et al. (2001).

In summary, the reverse senses associated with the seismic ruptures frozen in the study area can be compared with earthquakes with reverse-type focal mechanisms or 'down-dip compression' events. More particularly, the lack of normal kinematics associated with 
pseudotachylyte generation suggests that normal-type events such as those corresponding to reactivation at depth of normal faults formed in the slab before it starts subducting (e.g., Jiao et al., 2000; Barnhart et al., 2014) either did not occur in the Corsican subduction zone or did not leave any imprint.

\section{Conclusion}

The structural analysis of pseudotachylyte in the Cima di Gratera ophiolitic nappe leads to the following results.

Pseudotachylyte veins in the peridotite unit are either isolated and scattered in the unit or clustered in fault zones. Isolated veins as well as fault zones are horizontal (flat-lying type) or dip about $55^{\circ}$ (steeply dipping type). In fault zones, the abundance of fault veins likely reflects a large number of repeating seismic ruptures, among which some may correspond to small magnitude events like aftershocks. The lack of clear cross-cutting relationships suggests that the flat-lying fault zones and their steeply dipping equivalents were active alternatively, as a consequence of oscillating stress states possibly resulting from periodic unlocking of the shallow plate interface during the seismic cycle. The activity of the flat-lying fault zones probably lasted for a longer time than the steeply dipping fault zones. The sense of displacement associated with steeply dipping fault zones and with most of the flat-lying fault zones is top-to-the-west or top-to-the northwest. Cataclasite flanking most of the veins was formed before or coevally with frictional melting and likely mechanically weakened the peridotite, facilitating subsequent seismic rupture.

The base of the metagabbro unit is mylonitic. The origin of the mylonitization remains undetermined. The scenario retained here suggests that the ductile deformation was achieved in the subducting slab below the brittle-ductile transition depth of the gabbro. The isotherm corresponding to the brittle-ductile transition depth of the gabbro can be taken as parallel to the crust-mantle boundary in the subducting slab. Pseudotachylyte veins in the metagabbro are distributed in the lower part of the unit, in the foliated sole as well as in the equant metagabbro above. They are not as well organized as their equivalents in the peridotite unit. Flat-lying veins are abundant near the contact with the underlying peridotite, steeply dipping veins are scattered in the lower part of the unit. The ductile deformation affecting the base of the unit allows to distinguish pre-mylonitization pseudotachylyte formed above the brittleductile transition depth of the gabbro from post-mylonitization veins formed below this depth. In the equant metagabbro, it is no longer possible to distinguish more than one episode of pseudotachylyte formation. No information regarding the sense of displacement associated 
with seismic ruptures could be retrieved from gabbro pseudotachylyte veins, whatever their positions or attitudes. It is furthermore not possible to establish a relative chronology between pseudotachylyte formed on either side of the contact $\varphi_{2}$ between the peridotite and metagabbro units.

Depth constraints provided by the metamorphic conditions recorded by metagabbro pseudotachylyte (1.9-2.6 GPa pressure range, Deseta et al., 2014 a and b) and geometry as well as kinematics data from peridotite pseudotachylyte show similarities with well documented seismic ruptures occurring in the Wadati-Benioff zone of the Pacific plate beneath NE Japan. These similarities allow to propose a scenario of formation of pseudotachylyte which encompasses shallow seismic ruptures along the crust-mantle boundary as suggested by Singh et al. (2008) for the 2004 Sumatra earthquake and deeper ruptures in the Wadati-Benioff zone (60-100 km depth range). In this scenario, seismic ruptures in the subducting mantle would always occur under brittle conditions while those in the lower part of the subducting crust would partly be coeval with ductile deformation. No relative chronology between pseudotachylyte of either side of $\varphi_{2}$ (peridotite $v s$. metagabbro) can be firmly established. A part of the metagabbro post-mylonitization veins could be the result of large ruptures nucleated in the peridotite unit and propagated upward across $\varphi_{2}$ and through a metagabbro sole under ductile conditions.

Deciphering intermediate-depth seismicity from ophiolite-hosted pseudotachylyte is a complex task because rocks may have recorded earthquakes elsewhere than in the subducting slab. The rocks may have been deformed, at least partly, at the axial ridge during oceanic accretion or in the continent-ocean transition, during initial crustal thinning. Final ophiolite emplacement, whatever by obduction or collision, and subsequent episodes (e.g., late- to postorogenic extension) are also responsible for additional deformation. All these deformation episodes may contribute to clutter the final picture. However, like for the continental lithosphere (Swanson, 1992; Obata and Karato, 1995; Allen, 2005; Di Toro and Pennacchioni, 2005; Ueda et al., 2008), pseudotachylyte is a valuable tool to improve our understanding of the mechanics of the seismic ruptures in the oceanic lithosphere, in complement to geophysical studies.

\section{Acknowledgements.}


This work was funded by the CNRS-INSU TelluS-ALEAS program. Electronic microscopy was supported by the RENATECH Network. Reviews by G. Di Toro and an anonymous reviewer significantly helped clarifying several points of the paper.

\section{REFERENCES}

Abers, G.A., Nakajima, J., van Keken, P.E., Kita, S., Hacker, B.R., 2013. Thermal-petrological controls on the location of earthquakes within subducting plates. Earth and Planetary Science Letters 369-370, 178-187, 10.1016/j.eps1.2013.03.022.

Agard, P., Vitale-Brovarone, A., 2013. Thermal regime of continental subduction: The record from exhumed HP-LT terranes (New Caledonia, Oman, Corsica). Tectonophysics 601, 206-215, 10.1016/j.tecto.2013.05.011.

Allen, J.L., 2005. A multi-kilometer pseudotachylyte system as an exhumed record of earthquake rupture geometry at hypocentral depths (Colorado, USA). Tectonophysics 402, 37-54.

Andersen, T., Austrheim, H., 2006. Fossil earthquakes recorded by pseudotachylytes in mantle peridotite from the Alpine subduction complex of Corsica. Earth and Planetary Science Letters 242, 58-72.

Andersen, T.B., Mair, K., Austrheim, H., Podladchikov, Y.Y., Vrijmoed, J.C., 2008. Stress release in exhumed intermediate and deep earthquakes determined from ultramafic pseudotachylyte. Geology 36, 995-998.

Andersen, T.B., Austrheim, H., Deseta, N., Silkoset, P., Ashwal, L.D., 2014. Large subduction earthquakes along the fossil Moho in Alpine Corsica. Geology 42, 395-398.

Angiboust, S., Agard, P., Yamato, P., Raimbourg, H., 2012. Eclogite breccias in a subducted eclogite: A record of intermediate-depth earthquake? Geology 40, 707-710.

Apperson, K.D., Frohlich, C., 1987. The relationship between Wadati-Benioff zone geometry and $P, T$ and $B$ axes of intermediate and deep focus earthquakes. Journal of Geophysical Research 92, 13821-13831.

Arcay, D., 2012. Dynamics of interplate domain in subduction zones: influence of rheological parameters and subducting plate age. Solid Earth 3, 467-488.

Astiz, L., Lay, T., Kanamori, H., 1988. Large intermediate-depth earthquakes and the subduction process. Physics of the Earth and Planetary Interiors 53, 80-166.

Austrheim, H., Andersen, T.L., 2004. Pseudotachylytes from Corsica: Fossil earthquakes from subduction complex. Terra Nova 16, 193-197, 10.1111/j.1365-3121.2004.00551.x.

Barnhart, W.D., Hayes, G.P., Samsonov, S.V., Fielding, E.J., Seidman, L.E., 2014. Breaking the oceanic lithosphere of a subducting slab: The 2013 Khash, Iran earthquake. Geophysical Research Letters 41, 32-36, 10.1002/2013GL058096.

Braeck, S., Podladchikov, Y.Y., 2007. Spontaneous thermal runaway as an ultimate failure mechanism of materials. Physical Review Letters 98, 095504.

Brudzinski, M.R., Thurber, C.H., Hacker, B.R., Engdahl, E.R., 2007. Global prevalence of double Benioff zones. Science 316, 1472-1474, 10.1126/science.1139204. 

from ${ }^{40} \mathrm{Ar} /{ }^{39} \mathrm{Ar}$ ages on micas along a transect from Corsica to Tuscany. Tectonophysics 321, 127-155.

801 Cannat, M., Sauter, D., Escartin, J., Lavier, L., Picazo, S., 2009. Oceanic corrugated surfaces and the strength of the axial lithosphere at slow spreading ridges. Earth and Planetary Science Letters 288, 174-183.

803 Chen, P.F., Bina, C.R., Okal, E.A., 2004. A global survey of stress orientations in subducting slabs as revealed by

804 intermediate-depth earthquakes. Geophysical Journal International 159, 721-733, 10.1111/j.1365-246X.2004.02450.x.

805 Curewitz, D., Karson, J.A., 1999. Ultracataclasis, sintering, and frictional melting in pseudotachylytes from East Greenland.

806 Journal of Structural Geology 21, 1693-1713.

807 Davis, J.H., 1999. The role of hydraulic fractures and intermediate-depth earthquakes in generating subduction-zone 808 magmatism. Nature 398, 142-145.

809 Del Gaudio, P., Di Toro, G., Han, R., Hirose, T., Nielsen, S., Shimamoto, T., Cavallo, A., 2009. Frictional melting of 810 peridotite and seismic slip. Journal of Geophysical Research 114, B06306, 10.1029/2008JB005990.

811 Deseta, N., Andersen, T.B., Ashwal, L.D., 2014a. A weakening mechanism for intermediate-depth seismicity? Detailed 812 petrographic and microtextural observations from blueschist facies pseudotachylytes, Cape Corse, Corsica. Tectonophysics $813610,138-149$.

814 Deseta, N., Ashwal, L.D., Andersen, T.B., 2014b. Initiating intermediate-depth earthquakes: Insights from a HP-LT ophiolite 815 from Corsica. Lithos 206-207, 127-146.

816 Di Toro, G., Pennacchioni, G., 2004. Superheated friction-induced melts in zoned pseudotachylytes within the Adamello 817 tonalites (Italian Southern Alps). Journal of Structural Geology 26, 1783-1801.

818 Di Toro, G., Pennacchioni, G., 2005. Fault plane processes and mesoscopic structure of a strong-type seismogenic fault in 819 tonalites (Adamello batholith, Southern Alps). Tectonophysics 402, 55-80.

820 Dobson, D.P., Meredith, P.G., Boon, S.A., 2002. Simulation of subduction zone seismicity by dehydration of serpentine. 821 Science 298, 1407-1410.

822 Durand-Delga, M., Rossi, P., 2002. About the Ligurian-Piemontese Jurassic Ocean on the transect Corsica-Apennines. 823 Comptes Rendus Géoscience 334, 227-228.

824 Fabbri, O., Lin, A.M., Tokushige, H., 2000. Coeval formation of cataclasite and pseudotachylyte in a Miocene forearc 825 granodiorite, southern Kyushu, Japan. Journal of Structural Geology 22, 1015-1025.

826 Faure, M., Malavieille, J., 1981. Etude structurale d'un cisaillement ductile : le charriage ophiolitique corse dans la région de 827 Bastia. Bulletin de la Société Géologique de France 23, 335-343.

828 Fournier, M., Jolivet, L., Goffé, B., Dubois, R., 1991. Alpine Corsica Metamorphic Core Complex. Tectonics 10, $1173-1186$.

829 Frohlich, C., 2006. Deep earthquakes. Cambridge University Press, Cambridge, 573 p.

830 Green, H.W., Burnley, P.C., 1989. A new self-organizing mechanism for deep-focus earthquakes. Nature 341, $733-737$. 
833 Green. H.W., Houston, H., 1995. The mechanics of deep earthquakes. Annual Reviews of Earth and Planetary Sciences 23, 834 169-213.

835 Grocott, J., 1981. Fracture geometry of pseudotachylyte generation zones: a study of shear fractures formed during seismic

836 events. Journal of Structural Geology 3, 169-178.

837 Guerrera, F., Martin-Algarra, A., Perrone, V., 1993. Late Oligocene-Miocene syn-/-late-orogenic successions in Western and

838 Central Mediterranean Chains from the Betic Cordillera to the Southern Apennines. Terra Nova 5, 525-544.

839 Hacker, B.R., Peacock, S.M., Abers, G.A., Holloway S.D., 2003. Subduction factory 2. Are intermediate-depth earthquakes

840 in subducting slabs linked to metamorphic dehydration reactions? Journal of Geophysical Research 108,

$841 \quad 10.1029 / 2001$ JB001129.

842 Hansen, L.N., Cheadle, M.J., John, B.E., Swapp, S.M., Dick, H.J.B., Tucholke, B.E., Tivey, M.A., 2013. Mylonitic

843 deformation at the Kane oceanic core complex: Implications for the rheological behavior of oceanic detachment faults.

844 Geochemistry, Geophysics, Geosystems 14, doi:10/1002/ggge.20184.

845 Harris, L., 1985. Progressive and polyphase deformation of the Schistes Lustrés in Cap Corse, Alpine Corsica. Journal of

846 Structural Geology 7, 637-650.

847 Hasegawa, A., Uchida, N., Igarashi, T., Matsuzawa, T., Okada, T., Miura, S., Suwa, Y., 2007. Asperities and Quasi-Static

848 Slips on the Subducting Plate Boundary East of Tohoku, Northeast Japan. In: The Seismogenic Zone of Subduction Thrust

849 Faults, edited by T.H. Dixon and J.C. Moore, Princeton University Press, 451-475.

850 Hasegawa, A., Umino, N., Takagi, A., 1978a. Double-planed structure of the deep seismic zone in the Northeastern Japan 851 arc. Tectonophysics $47,43-58$.

852 Hasegawa, A., Umino, N., Takagi, A., 1978b. Double-planed deep seismic zone and upper-mantle structure in the

853 Northeastern Japan arc. Geophysical Journal of the Royal Astronomical Society 54, 281-296.

854 Hasegawa, A., Nakajima, J., Uchida, N., Okada, T., Zhao, D., Matsuzawa, T., Umino, N., 2009. Plate subduction, and 855 generation of earthquakes and magmas in Japan as inferred from seismic observations: An overview. Gondwana Research 16, $856 \quad 370-400$.

857 Hilairet, N., Daniel, I., Reynard, B., 2006. Equation of state of antigorite, stability field of serpentines, and seismicity in 858 subduction zones. Geophysical Research Letters 33, L2302, 10.1029/2005GL024728.

859 Hirose, T., Bystricky, M., 2007. Extreme dynamic weakening of faults during dehydration by coseismic shear heating.

860 Geophysical Research Letters 34, L14311, 10.1029/2007GL030049.

861 Hirose, T., Mizoguchi, K., Shimamoto, T., 2012. Wear processes in rocks at slow to high slip rates. Journal of Structural

862 Geology 38, 102-116, 10.1016/j.jsg.2011.12.007.

863 Hoogerduijn-Strating, E.H., Vissers, R.L.M., 1991. Dehydration-induced fracturing of eclogite-facies peridotites:

864 implications for the mechanical behavior of subducting oceanic lithosphere. Tectonophysics 200, 187-198. 

329-354.

867 Igarashi, T., Matsuzawa, T., Umino, N., Hasegawa, A., 2001. Spatial distribution of focal mechanisms for interplate and 868 intraplate earthquakes associated with the subducting Pacific plate beneath the northeastern Japan arc- A triple-planed deep

869 seismic zone. Journal of Geophysical Research 106, 2177-2191.

870 Isacks, B., Molnar, P., 1971. Distribution of stresses in the descending lithosphere from a global survey of focal mechanism 871 solutions of mantle earthquakes. Reviews of Geophysics and Space Physics 9, 103-174.

872 Jiao, W., Silver, P.G., Fei, Y., Prewitt, C.T., 2000. Do intermediate- and deep-focus earthquakes occur on preexisting weak 873 zones? An examination of the Tonga subduction zone. Journal of Geophysical Research 105, 28125-28138.

874 John, T, Medvedev, S., Rüpke, L.H., Andersen, T.B., Podladchikov, Y.Y., Austrheim, H., 2009. Generation of intermediate875 depth earthquakes by self-localizing thermal runaway. Nature Geoscience 2, 137-140, 10.1038/NGEO419.

876 Jolivet, L., Daniel, J.M., Fournier, M., 1991. Geometry and kinematics of extension in Alpine Corsica. Earth and Planetary

877 Science Letters 104, 278-291.

878 Jolivet, L., Dubois, R., Fournier, M., Goffé, B., Michard, A. Jourdan, C., 1990. Ductile extension in Alpine Corsica. Geology $87918,1007-1010$.

880 Jolivet, L., Faccenna, C., Goffé, B., Mattei, M., Rossetti, F., Brunet, C., Storti, F., Funiciello, C., Cadet, J.P., D’Agostino, N., 881 Parra, T., 1998. Mid-crustal shear zones in post-orogenic extension: examples from the northern Tyrrhenian Sea case. Journal 882 of Geophysical Research 103, 12123-12160.

883 Jung, H., Green, H.W., Dobrzhinetskaya, L.F., 2004. Intermediate-depth earthquake faulting by dehydration embrittlement 884 with negative volume change. Nature 428, 545-549.

885 Kameyama, M., Yuen, D.A., Karato, S.I., 1999. Thermal-mechanical effects of low-temperature plasticity (the Peierls 886 mechanism) on the deformation of a viscoelastic shear zone. Earth and Planetary Science Letters 168, 159-172.

887 Kanamori, H., Anderson, D.L., Heaton, T.H., 1998. Frictional melting during the rupture of the 1994 Bolivian earthquake. 888 Science 279, 839-842.

889 Kao, H., Chen, W.P., 1995. Transition from interplate slip to double seismic zone along the Kuril-Kamchatka arc. Journal of

890 Geophysical Research 100, 9881-9903.

891 Kao, H., Liu, L.G., 1995. A hypothesis for the seismogenesis of a double seismic zone, Geophysical Journal International $892123,71-84$

893 Kelemen, P., Hirth, G., 2007. A periodic shear-heating mechanism for intermediate-depth earthquake in the mantle. Nature 894 446, 787-790.

895 Kirby, S., 1995. Interslab earthquake and phase changes in subducting lithosphere. Reviews of Geophysics 33 (suppl., Report 896 to International Union of Geodesy and Geophysics), 287-297.

897 Kirby, S., Durham, W., Stern, L., 1991. Mantle phase changes and deep-earthquake faulting in subducting lithosphere.

898 Science 252, p. 216-225. 

double seismic zone extending in the along-arc direction at depths of 70-100 km beneath NE Japan. Geophysical Research

Lacombe, O., Jolivet, L., 2005. Structural and kinematic relationships between Corsica and the Pyrenees-Provence domain at the time of the Pyrenean orogeny. Tectonics 24, TC1003, 10.1029/2004TC001673.

904 Lahondère, D., 1996. Les schistes bleus et les éclogites à lawsonite des unités continentales et océaniques de la Corse alpine, 905 Documents du BRGM 240, Orléans, 294 p.

906 Lahondère, D., Guerrot, C., 1997. Datation Sm-Nd du métamorphisme éclogitique en Corse alpine : un argument pour

907 l'existence, au Crétacé supérieur, d'une zone de subduction active localisée le long du bloc corso-sarde. Géologie de la Franc 908 3, 3-11.

909 Lahondère, J.C., 1981. Relations du "socle ancien" de la région de Bastia (Corse) avec les Schistes lustrés environnants.

910 Comptes Rendus de l'Académie des Sciences, 293, 169-172.

911 Li, X.H., Faure, M., Rossi, P., Lahondère, D., 2015. Age of Alpine Corsica ophiolites revisited: Insights from in situ zircon

912 U-Pb age and O-Hf isotopes. Lithos, 220-223, 179-190.

913 Maddock, R.H., 1992. Effects of lithology, cataclasis and melting on the composition of fault-generated pseudotachylytes in

914 Lewisian gneiss, Scotland. Tectonophysics 204, 261-278.

915 Maggi, M., Rossetti, F., Corfu, F., Theye, T., Andersen, T.B., Faccenna, C., 2012. Clinopyroxene-rutile phyllonites from the 916 East Tenda Shear Zone (Alpine Corsica, France): pressure-temperature-time constraints to the Alpine reworking of Variscan

917 Corsica. Journal of the Geological Society 169, 723-732.

918 Magloughlin, J., 1992. Microstructural and chemical changes associated with cataclasis and frictional melting at shallow 919 crustal levels: the cataclasite-pseudotachylyte connection. Tectonophysics 204, 243-260.

920 Manatschal G., Müntener, O., 2009. A type sequence across an ancient magma-poor ocean-continent transition: the example 921 of the western Alpine Tethys ophiolites. Tectonophysics 473, 4-19.

922 Marroni, M., Pandolfi, L. 2007. The architecture of an incipient oceanic basin: a tentative reconstruction of the Jurassic 923 Liguria-Piemonte basin along the Northern Apennines-Alpine Corsica transect. International Journal of Earth Sciences 96, 924 1059-1078.

925 Martin, L.A.J., Rubatto, D., Vitale-Brovarone, A., Hermann, J., 2011. Late Eocene lawsonite-eclogite facies metasomatism 926 of a granitic sliver associated to ophiolites in Alpine Corsica. Lithos 125, 620-640.

927 Martinez-Diaz, J.J., Alvarez-Gomez, J.A., Benito, B., Hernandez, D., 2004. Triggering of destructive earthquakes in E1 928 Salvador. Geology 32, 65-68, 10.1130/G20089.1.

929 Mattauer, M., Proust, F., 1976. La Corse alpine: un modèle de genèse du métamorphisme haute pression par subduction de 930 croûte continentale sous du matériel océanique. Comptes Rendus de l'Académie des Sciences 282, 1249-1252.

931 Mattauer, M., Proust, F., Etchecopar, A., 1977. Linéation 'a'” et mécanisme de cisaillement simple liés au chevauchement de 932 la nappe des schistes lustrés en Corse. Bulletin de la Société Géologique de France 29, 841-847. 
935 McNulty, B.A., 1995. Pseudotachylytes generated in the semi-brittle and brittle regimes, Bench Canyon shear zone, central 936 Sierra Nevada. Journal of Structural Geology 17, 1507-1521.

937 Meresse, F., Lagabrielle, Y., Malavielle, J., Ildefonse, B., 2012. A fossil Ocean-Continent Transition of the Mesozoic Tethys

938 preserved in the Schistes Lustrés nappe of northern Corsica. Tectonophysics 579, 4-16.

939 Molli, G., 1994. Microstructural features of high temperature shear zones in gabbros of the Northern Apennine ophiolites.

$940 \quad$ Journal of Structural Geology 16, 1535-1541.

941 Molli, G., 2008. Northern Apennine-Corsica orogenic system: an updated overview. In Siegesmund, S., Fügenschuh, B.,

942 Froitzheim, N. (Eds.), Tectonic Aspect of the Alpine-Dinaride-Carpathian System: Geological Society of London, Special

943 Publication 298, 413-442.

944 Molli, G., Malavieille, J., 2010. Orogenic process and the Corsica/Apennine geodynamic evolution: Insight from Taiwan.

945 International Journal of Earth Sciences 100, 1207-1224, 10.1007/s00531-010-0598-y.

946 Nakajima, J., Tsuji, Y., Hasegawa, A., Kita, S., Okada, T., Matsuzawa, T., 2009. Tomographic imaging of hydrated crust and

947 mantle in the subducting Pacific slab beneath Hokkaido, Japan: Evidence for dehydration embrittlement as a cause of

948 intraslab earthquakes. Gondwana Research 16, 470-481.

949 Nakajima, J., Uchida, N., Shiina, T., Hasegawa, A., Hacker, B.R., Kirby, S.H., 2013. Intermediate-depth earthquakes

950 facilitated by eclogitization-related stresses. Geology 41, 659-662, 10.1130/G33796.1.

951 Obata, M., Karato, S.I., 1995. Ultramafic pseudotachylytes from Balmuccia peridotite, Ivrea-Verbano zone, northern Italy.

952 Tectonophysics 242, 313-328.

953 Ogawa, M., 1987. Shear instability in a viscoelastic material as the cause of deep focus earthquakes. Journal of Geophysical

954 Research 92, 13801-13810.

955 Ohnenstetter, M., Ohnenstetter, D., Vidal, P., Cornichet, J., Hermitte, D., Mace, J., 1981. Crystallization and age of zircon

956 from Corsican ophiolitic albitites: consequences for oceanic expansion in Jurassic times. Earth and Planetary Science Letters $95754,397-408$.

958 Okada, T., Hasegawa, A., 2003. The M7.1 May 26, 2003 off-shore Miyagi Prefecture Earthquake in northeast Japan: Source 959 process and aftershock distribution of an intra-slab event. Earth, Planets, Space 55, 731-739.

960 Padron-Navarta, J.A., Hermann, J., Garrido, C.J., Sanchez-Vizcaino, V.L., Gomez-Pugnaire, M.T., 2010. An experimental

961 investigation of antigorite dehydration in natural silica-enriched serpentinites. Contributions to Mineralogy and Petrology

$962159,25-42,10.1007 /$ s00410-009-0414-5.

963 Passchier, C., 1982. Pseudotachylyte and the development of ultramylonite bands in the Saint-Barthelemy Massif, French

964 Pyrenees. Journal of Structural Geology 4, 69-79.

965 Peacock, S.M., 2001. Are the lower planes of double seismic zones caused by serpentine dehydration in subduction oceanic

966 mantle? Geology 29, 299-302. 
969 Piccardo, G.B., 2008. The Jurassic Ligurian Tethys, a fossil ultra-slow spreading ocean: The mantle perspective. In: Coltorti,

970 M., Grégoire, M. (Eds.), Metasomatism in oceanic and continental lithospheric mantle: Geological Society of London Special

971 Publication 294, 11-33.

972 Piccardo, G.B., Ranalli, G., Marasco, M., Padovano, M., 2007. Ultramafic pseudotachylytes in the Mt. Moncuni peridotite

973 (Lanzo Massif, western Alps): tectonic evolution and upper mantle seismicity. Periodico di Mineralogia 76, 181-197,

974 10.2451/2007PM0024.

975 Piccardo, G.B., Ranalli, G., Guarnieri, L., 2010. Seismogenic shear zone in the lithospheric mantle: Ultramafic

976 pseudotachylytes in the Lanzo peridotite (Western Alps, NW Italy). Journal of Petrology 51, 81-100,

977 doi:10.1093/petrology/egp067.

978 Preston, L.A., Creager, K.C., Crosson, R.S., Brocher, T.M., Trehu, A.M., 2003. Intraslab earthquakes: Dehydration of the 979 Cascadia Slab. Science 302, 1197-1200.

980 Prieto, G.A., Florez, M., Barrett, S.A., Beroza, G.C., Pedraza, P., Blanco, J.F., Podeva, E., 2013. Seismic evidence for

981 thermal runaway during intermediate-depth earthquake rupture. Geophysical Research Letters 40, 6064-6068,

$98210.1002 / 2013$ GL058109.

983 Raleigh, C.B., Paterson, M.S., 1965. Experimental deformation of serpentinite and its tectonic implications. Journal of

984 Geophysical Research 70, 3965-3985.

985 Rampone E., Hofmann, A.W., Raczek, I., 2009. Isotopic equilibrium between mantle peridotite and melt: Evidence from the 986 Corsica ophiolite. Contributions to Mineralogy and Petrology 156, 453-475, 10.1007/s00410-008-0296-y.

987 Rampone, E. Piccardo, G.B., 2000. The ophiolite-oceanic lithosphere analogue: new insights from the Northern Apennines 988 (Italy). Geological Society of America Special Paper 349, 21-34.

989 Ravna, E.J.K., Andersen, T.B., Jolivet, L., De Capitani, C., 2010. Cold subduction and the formation of lawsonite eclogite 990 constraints from prograde evolution of eclogitized pillow lava from Corsica. Journal of Metamorphic Geology 28, 381-395.

991 Rondenay, S., Abers, G.A., van Keken, P.E., 2008. Seismic imaging of subduction zone metamorphism. Geology 36, 275-

$992 \quad 278,10.1130 / \mathrm{G} 24112 \mathrm{~A} .1$.

993 Rosenbaum, G., Lister, G.S., Duboz, C., 2002. Relative motions of Africa, Iberia and Europe during Alpine orogeny.

994 Tectonophysics 359, 117-129.

995 Rossi, P., Cocherie, A., Lahondère, D., Fanning, N., 2002. La marge européenne de la Téthys jurassique en Corse : Datation

996 de trondhjémites de Balagne et indices de croûte continentale sous le domaine Balagno-Ligure. Comptes Rendus Géoscience $997334,313-322$.

998 Rowe, C.D., Moore, J.C., Meneghini, F., McKeirnan, A.W., 2005. Large-scale pseudotachylytes and fluidized cataclasites 999 from an ancient subduction thrust fault. Geology 33, 937-940, 10.1130/G21856.1.

1000 Rutter, E. H., Brodie, K. H. (1988). Experimental "syntectonic" dehydration of serpentinite under conditions of controlled 1001 pore water pressure. Journal of Geophysical Research 93, 4907-4932. 
Scambelluri, M., Hoogerduijn-Strating, E.H., Piccardo, G.B., Vissers, R.L.M., Rampone, E., 1991. Alpine olivine- and clinohumite-bearing assemblages in the Erro-Tobbio peridotite (Voltri Massif, NW Italy). Journal of Metamorphic Geology 9, 79-91.

Schubnel, A., Brunet, F., Hilairet, N., Gasc, J., Wang, Y., Green, H.W., 2013. Deep-focus earthquake analogs recorded at high pressure and temperature in the laboratory. Science 341, 1377-1380, 10.1126/science.1240206.

Seno, T., Yamanaka, Y., 1996. Double seismic zones, compressional deep trench-outer rise events, and superplumes. In: Subduction Top to Bottom. Geophysical Monograph 96, edited by G. E. Bebout et al., pp. 347-355, AGU, Washington, D.C., 347-355.

Seno, T., Zhao, D., Kobayashi, Y., Nakamura, M., 2001. Dehydration of serpentinized slab mantle: Seismic evidence from southwest Japan. Earth, Planets, Space 53, 861-871.

Sibson, R.H., 1975. Generation of pseudotachylytes by ancient seismic faulting. Royal Astronomical Society Geophysical Journal 43, 775-794.

Sibson, R.H., 1980. Transient discontinuities in ductile shear zones. Journal of Structural Geology 2, 165-171.

Sibson, R.H., 1986. Brecciation processes in fault zones: Inferences from earthquake rupturing. Pure and Applied Geophysics $124,159-175$.

Singh, S.C., Carton, H., Tapponnier, P., Hananto, N.D., Chauhan, A.P.S., Hartoyo, D., Bayly, M., Moeljopranoto, S., Bunting, T., Christie, P., Lubis, H., Martin, J., 2008. Seismic evidence for broken oceanic crust in the 2004 Sumatra earthquake epicentral region. Nature Geoscience 1, 777-781, 10.1038/ngeo336.

Singh, S.C., Hananto, N., Mukti, M., Permana, H., Djajadihardja, Y., Harjono, H., 2011. Seismic images of the megathrust rupture during the 25th October 2010 Pagai earthquake, SW Sumatra: Frontal rupture and large tsunami. Geophysical Research Letters 38, L16313, 10.1029/2011GL048935.

Souquière, F., Fabbri, O., 2010. Pseudotachylytes in the Balmuccia peridotite (Ivrea Zone) as markers of the exhumation of the southern Alpine continental crust. Terra Nova 22, 70-77.

Spray, J.G., 1995. Pseudotachylyte controversy: Fact or friction? Geology 23, 1119-1122.

Stampfli, G.M., Mosar, J., Marquer, D., Marchant, R., Baudin, T., Borel, G., 1998. Subduction and obduction processes in the Alps. Tectonophysics 296, 159-204.

Stünitz, H., 1993. Transition from fracturing to viscous flow in a naturally deformed metagabbro. In: Defects and processes in the solid state: Geoscience applications (Boland, J.N. and Fitz Gerald, J.D. editors). Elsevier, Amsterdam, 121-150.

Swanson, M.T., 1988. Pseudotachylyte-bearing strike-slip duplex structures in the Fort Foster Brittle Zone, S. Maine. Journal of Structural Geology 10, 813-828.

Swanson, M.T., 1992. Fault structure, wear mechanisms and rupture processes in pseudotachylyte generation. Tectonophysics 204, 223-242.

Tsuji, T., Kodaira, S., Ashi, J., Park, J.O., 2013. Widely distributed thrust and strike-slip faults within subducting oceanic crust in the Nankai Trough off the Kii Peninsula, Japan. Tectonophysics 600, 52-62. 
Tsuji, T., Park, J.O., Moore, G., Kodaira, S., Fukao, Y., Kuramoto, S.I., Bangs, N., 2009. Intraoceanic thrusts in the Nankai Trough off the Kii Peninsula: Implications for intraplate earthquakes. Geophysical Research Letters 36, L06303, 10.1029/2008GL036974.

Tucholke, B.E., Lin, J., 1994. A geological model for the structure of ridge segments in slow spreading ocean crust. Journal of Geophysical Research 99, 11937-11958.

Turco, E., Macchiavelli, C., Mazzoli, S., Schettino, A., Pierantoni, P.P., 2012. Kinematic evolution of Alpine Corsica in the framework of Mediterranean mountain belts. Tectonophysics 579, 193-206.

Ulmer, P., Trommsdorff, V., 1995. Serpentine stability to mantle depths and subduction-related magmatism. Science 268, 858-861.

Ueda, T., Obata, M., Di Toro, G., Kanagawa, K., Ozawa, K., 2008. Mantle earthquake frozen in mylonitized ultramafic pseudotachylytes of spinel-lherzolite facies. Geology 36, 607-610.

Vallée, M., Bouchon, M., Schwartz, S.Y., 2003. The 13 January 2001 El Salvador earthquake: A multidata analysis. Journal of Geophysical Research 108, 2203, 10.1029/2002JB001922.

Vitale-Brovarone, A., Beltrando, M., Malavielle, J., Giuntoli, F., Tondella, E., Groppo, C., Beyssac, O., Compagnoni, R., 2011. Inherited Ocean-Continent Transition zones in deeply subducted terranes: Insight from Alpine Corsica. Lithos 124, 273-290.

Vitale-Brovarone, A., Beyssac, O., Malavielle, J., Molli, G., Beltrando, M., Compagnoni, R., 2013. Stacking and metamorphism of continuous segments of subducted lithosphere in a high-pressure wedge: The example of Alpine Corsica (France). Earth Science Reviews 116, 35-56, doi:10.1016/j.earscirev.2012.10.003.

Vitale-Brovarone, A., Herwartz, D., 2013. Timing of HP metamorphism in the Schistes Lustrés of Alpine Corsica: New LuHf garnet and lawsonite ages. Lithos 172-173, 175-191.

Vitale-Brovarone, A., Picatto, M., Beyssac, O., Lagabrielle, Y., Castelli, D., 2014. The blueschist-eclogite transition in the Alpine chain: P-T paths and the role of slow spreading extensional structures in the evolution of HP-LT mountain belts. Tectonophysics 615-616, 96-121.

Wang, K., 2002. Unbending combined with dehydration embrittlement as a cause for double and triple seismic zones. Geophysical Research Letters 29, 1889, 10.1029/2002GL015441.

Wang, K., Cassidy, J.F., Wada, I., Smith, A.J., 2004. Effects of metamorphic crustal densification on earthquake size in warm slabs. Geophysical Research Letters 31, L01605, 10.1029/2003GL018644.

Warburton, J., 1986. The ophiolite-bearing Schistes Lustrés nappe in Alpine Corsica: A model for the emplacement of ophiolites that have suffered HP/LP metamorphism. In: Blueschists and Eclogites (B.W. Evans and E.H. Brown, eds). Geological Society of America Memoir 164, 313-331.

Wenk, H.R., Johnson, L.R., Ratschbacher, L., 2000. Pseudotachylites in the Eastern Peninsular Ranges of California. Tectonophysics 321, 253-277.

Wiens, D.A., McGuire, J.J., Shore, P.J., 1993. Evidence for transformational faulting from a deep double seismic zone in Tonga. Nature 364, 790-793, 10.1038/364790a0. 
Wiens, D.A., Snider N.O., 2001. Repeating deep earthquakes: Evidence for fault reactivation at great depth. Science 293, $1465-1466$.

Wunder, B., Schreyer, W., 1997. Antigorite: High-pressure stability in the system $\mathrm{MgO}-\mathrm{SiO}_{2}-\mathrm{H}_{2} \mathrm{O}(\mathrm{MSH})$. Lithos 41, $213-$ 227, 10.1016/S0024-4937(97)82013-0.

Yamasaki, T., Seno, T., 2003. Double seismic zone and dehydration embrittlement of the subducting slab. Journal of Geophysical Research 108, 1-21.

Yoshii, T., 1979. A detailed cross-section of the deep seismic zone beneath northeastern Honshu, Japan. Tectonophysics 55, 349-360.

Zechmeister, M.S., Ferré, E.C., Cosca, M.A., Geissman, J.W., 2007. Slow and fast deformation in the Dora Maira Massif, Italian Alps: Pseudotachylytes and inferences on exhumation history. Journal of Structural Geology 29, 1114-1130.

Figure captions

Figure 1. Structural map of the study area (modified after Faure and Malavieille, 1981, Lahondère, 1996 and Meresse et al., 2012) and lower-hemisphere equal-area projections of poles to pseudotachylyte fault veins in the peridotite unit. Arrows indicate the sense of shear associated with pseudotachylyte fault veins. The locations of cross-sections A-A' and B-B' (see Fig. 2) are shown. CdG: Cima di Gratera; PdM: Punta di Muzzelli.

Figure 2. Geological cross-sections of the study area (location in Fig. 1).

Figure 3. Examples of outcrop-scale top-to-the-west or top-to-the-northwest displacement sense criteria from the flat-lying fault zones in the peridotite unit. A, B and C: West-dipping or northwest-dipping Riedel-like pseudotachylyte-coated normal faults (labeled by R) offsetting earlier fault veins. A and B from locality 6, C from locality 5. D: Southeast-dipping pseudotachylyte-coated reverse faults offsetting earlier fault veins at locality 3.

Figure 4. Polished surface (A) and corresponding sketches (B and C) of a peridotite hand sample from the upper flat-lying fault zone at locality 2 (Fig. 1) showing two stages of pseudotachylyte formation. The kinematics associated with the early pseudotachylyte veins is undetermined, while that associated with the late pseudotachylyte veins is top-to-the-west $\left(\mathrm{N} 280^{\circ} \mathrm{E}\right)$. Rectangle on $(\mathrm{A})$ corresponds to the thin section scanner image of Fig. 10C.

Figure 5. Detailed field view (A) and corresponding sketch (B) of a steeply-dipping reverse fault zone (locality 2) showing anastomosed fault veins crossing cataclastic peridotite.

Figure 6. Polished surface (A) and corresponding sketch (B) of a peridotite hand sample from the steeply-dipping fault zone of locality 2 showing three stages of pseudotachylyte 
formation. Senses of shear of the intermediate and late seismic ruptures are top-to-thenorthwest $\left(\mathrm{N} 320^{\circ} \mathrm{E}\right)$. Rectangle on (A) corresponds to Fig. 10D.

Figure 7. Thin section scanner images, SEM images and photomicrographs of microlitic-type and annealed-type pseudotachylyte veins in the peridotite. A: Thin section scanner image of a microlitic-type fault vein showing a zonation parallel to the boundaries with the host rock (locality 3). B: Chilled margin (C.m) of a microlitic-type fault vein showing a sharp decrease in microlite size. Microlites consist of olivine and pyroxene (locality 1). C: Pyroxene microlites in an injection vein (locality 4). D: Annealed-type fault vein from locality 4. Arrows indicate cooling cracks. Square is for E. E: SEM image of D showing olivine with a granoblastic annealed texture.

Figure 8. Examples of pseudotachylyte-cataclasite associations in the peridotite-hosted steeply dipping fault zone at locality 2. A: Photomicrograph. (B) Thin section scanner image. Ct: cataclasite; Pct: proto-cataclasite; Pst: pseudotachylyte; Uc: ultra-cataclasite.

Figure 9. SEM images of associated cataclasites and pseudotachylytes in peridotite from locality 6. A: From top left to bottom right, juxtaposition of proto-cataclasite (PCt), cataclasite $(\mathrm{Ct})$, pseudotachylyte (Pst) and moderately fractured peridotite (wall). B: Detail of the Ct-Psthost rock zoned domain of (A). C: Detail of the Ct domain of (A), showing angular clasts. D: Detailed view of a cataclasite-wall rock contact.

Figure 10. Thin section scanner images and photomicrographs of fault veins from the steeply dipping fault zone at locality 2 (A and B) and from the flat-lying fault zone at locality 3 (C, D and E) showing top-to-the-west or top-to-the-northwest displacement senses. A: Parallel polarized thin section scanner image showing an anastomosed network of steeply dipping cataclasite zones with a reverse displacement sense. B: Crossed-polar enlarged image from (A) showing cataclastic zones offsetting olivine crystals in a reverse sense. C: Parallel-polar thin section scanner image of a pseudotachylyte vein and associated sheared peridotite suggesting a top-to-the-west sense of displacement. D: Parallel-polar thin section scanner image showing an early steeply dipping pseudotachylyte vein left-laterally offset by a late flat-lying pseudotachylyte vein. E: Detail of D showing that the flat-lying vein is younger than the vein dipping to the right.

Figure 11. Outcrop aspect of pre- and post-mylonitization pseudotachylyte veins in the foliated metagabbro sole at locality 4 and attitudes of nearby post-mylonitization veins. A: Foliated metagabbro showing a post-mylonitization fault vein secant on pre-mylonitization 
fault veins and on foliation. The foliation is outlined by the dashed red line. Red arrows point at pre-mylonitization fault veins. B: Lower-hemisphere equal-area projection of poles to postmylonitization fault veins (solid circles) and poles to foliation (red triangles).

Figure 12. Microscopic aspect of pre- and post-mylonitization pseudotachylyte veins in the foliated sole of the metagabbro unit. A: Parallel-polar thin section scanner image of the foliated metagabbro. B: Detail of A showing a mylonitized pseudotachylyte vein. The foliation inside the vein is slightly oblique to the foliation outside, likely because of some obliquity of the vein with respect to the deformation axes. C: Parallel-polar thin section scanner image showing a post-mylonitization fault vein, a post-mylonitization injection vein and a foliated pre-mylonitization vein. D: sketch of C. Pre-myl. Pst: pre-mylonitization vein; Post-myl. Pst: post-mylonitization vein. Dashed lines outline the foliation trace.

Figure 13. Multi-stage scenario of formation of pseudotachylyte and mylonite in the Cima di Gratera nappe. A: General sketch showing the east-dipping subduction of the PiemonteLiguria oceanic basin beneath an arc or a micro-continent in Cretaceous times. Also depicted are the hypocenters (asterisks) of the Wadati-Benioff seismic zone. B: Formation of premylonitization pseudotachylyte at shallow depth at or near the mantle-crust boundary. C: Ductile deformation of the base of the oceanic crust and coeval formation of pseudotachylyte in the underlying peridotite. D: Formation of post-mylonitization veins in the ductilely deforming metagabbro by seismic ruptures nucleated in the peridotite and having propagated upward across and beyond the foliated metagabbro.

Figure 14. Geometrical and kinematic similarities between the present-day seismic activity of the Wadati-Benioff zone beneath NE Japan (A and B) and the Corsican fossil seismic ruptures (C and D). A: Possible location of the Corsican seismic ruptures (rectangle) in a cold slab thermal model (isotherms after Peacock, 2001 and Hacker et al., 2003). B: Hypocenters and kinematics of the 2002-2003 seismic activity in the uppermost part of the Pacific plate off NE Japan (Hasegawa et al., 2007). The red rectangle delineates the possible equivalent of the seismic fault zones frozen in Corsica. C: Sketch summarizing the geometry and kinematics of the Corsican fossil seismic ruptures in the peridotite unit (approximate width: $5 \mathrm{~km}$ ). D: Detail of $\mathrm{C}$ emphasizing large ruptures propagating upwards across the crust-mantle boundary and beyond the foliated basal metagabbro (approximate width: $1 \mathrm{~km}$ ). 


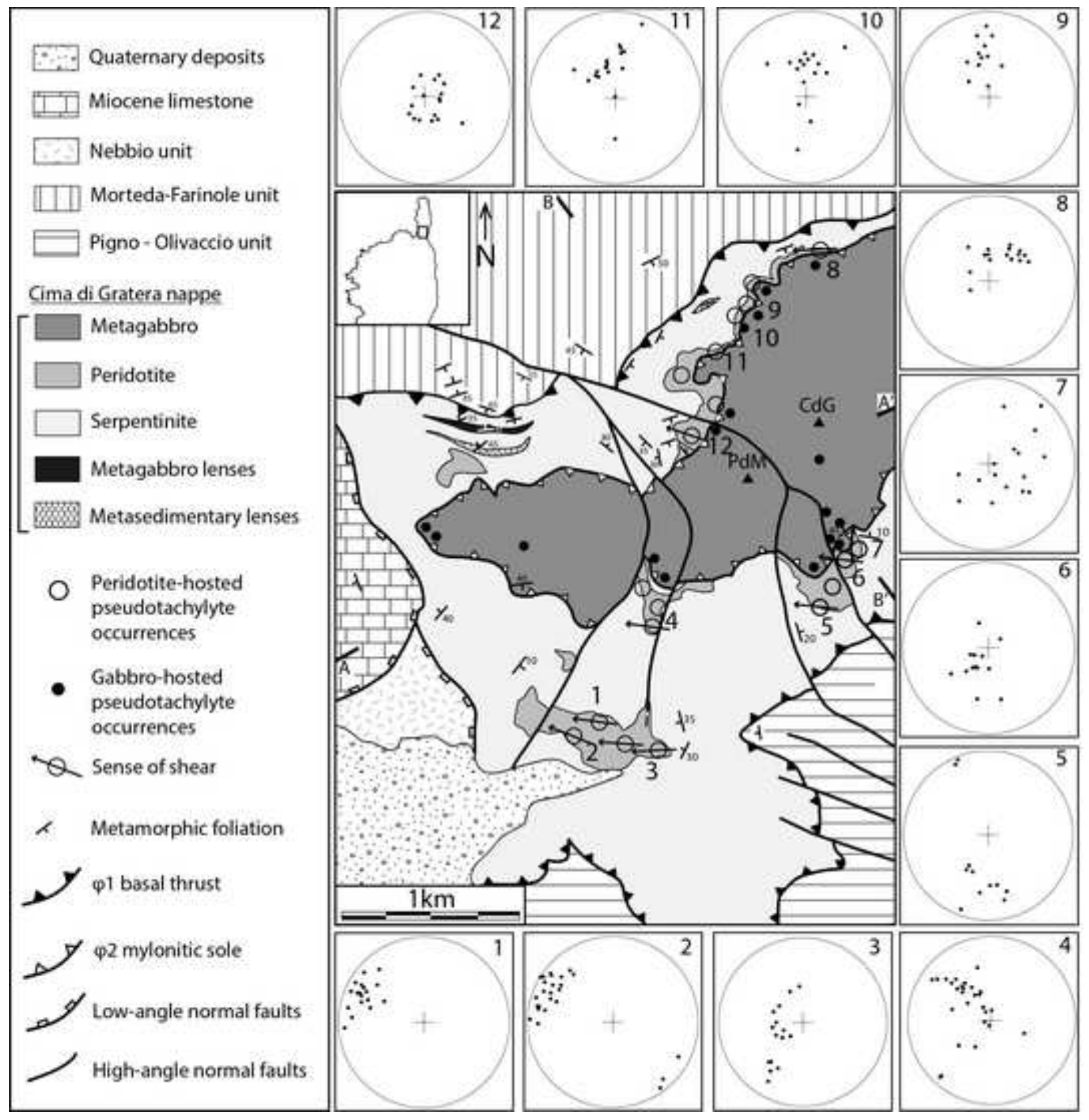




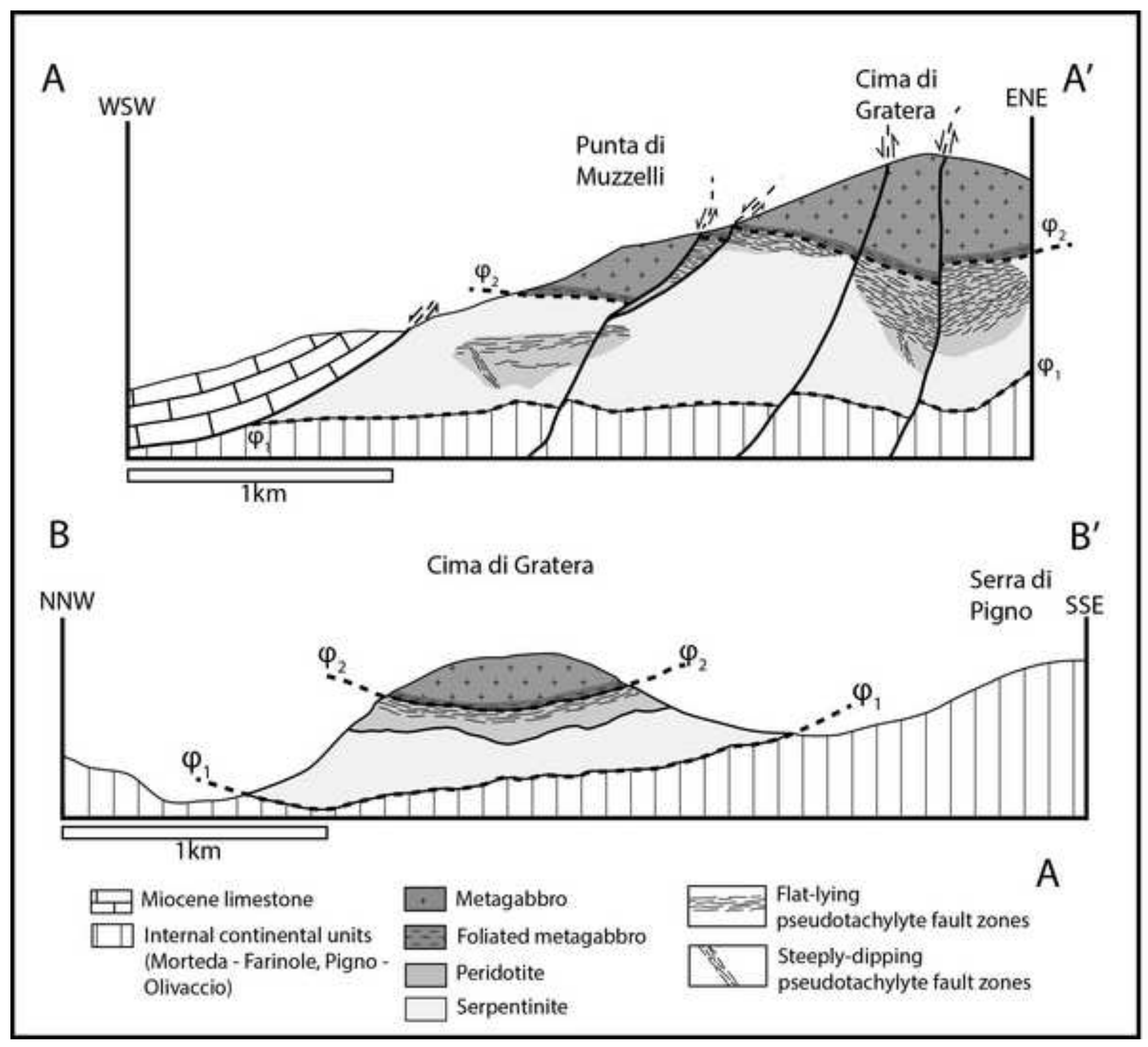



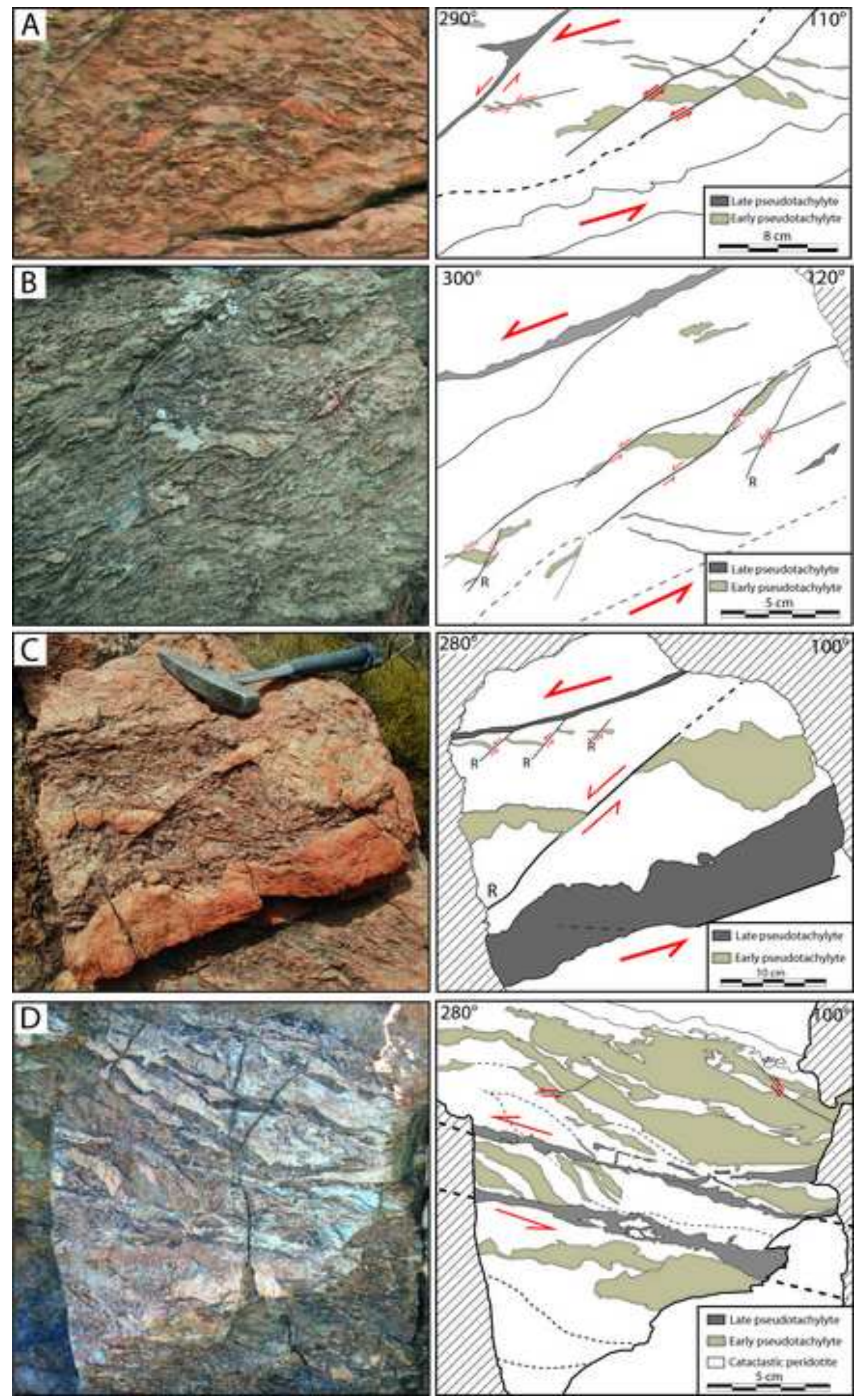

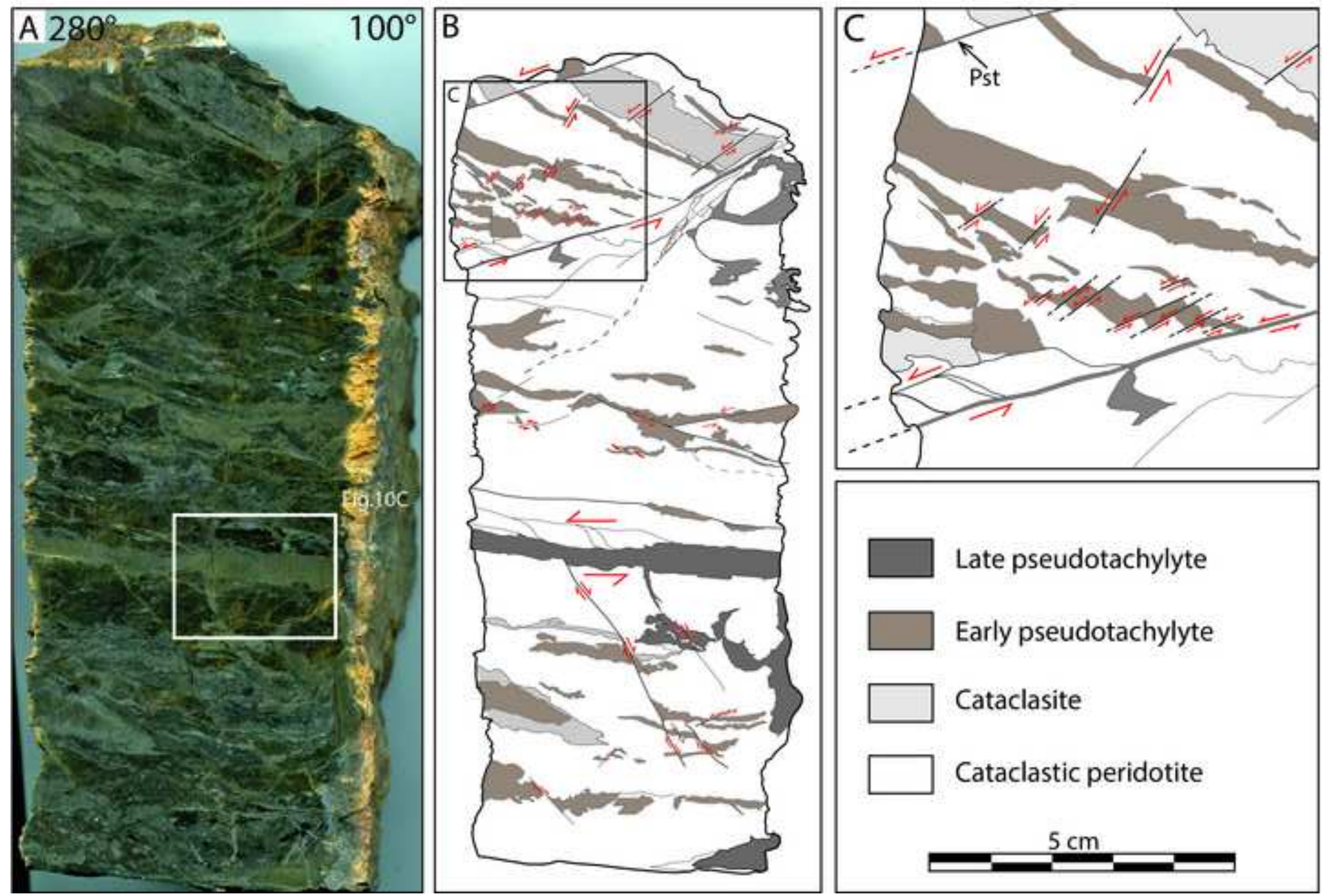

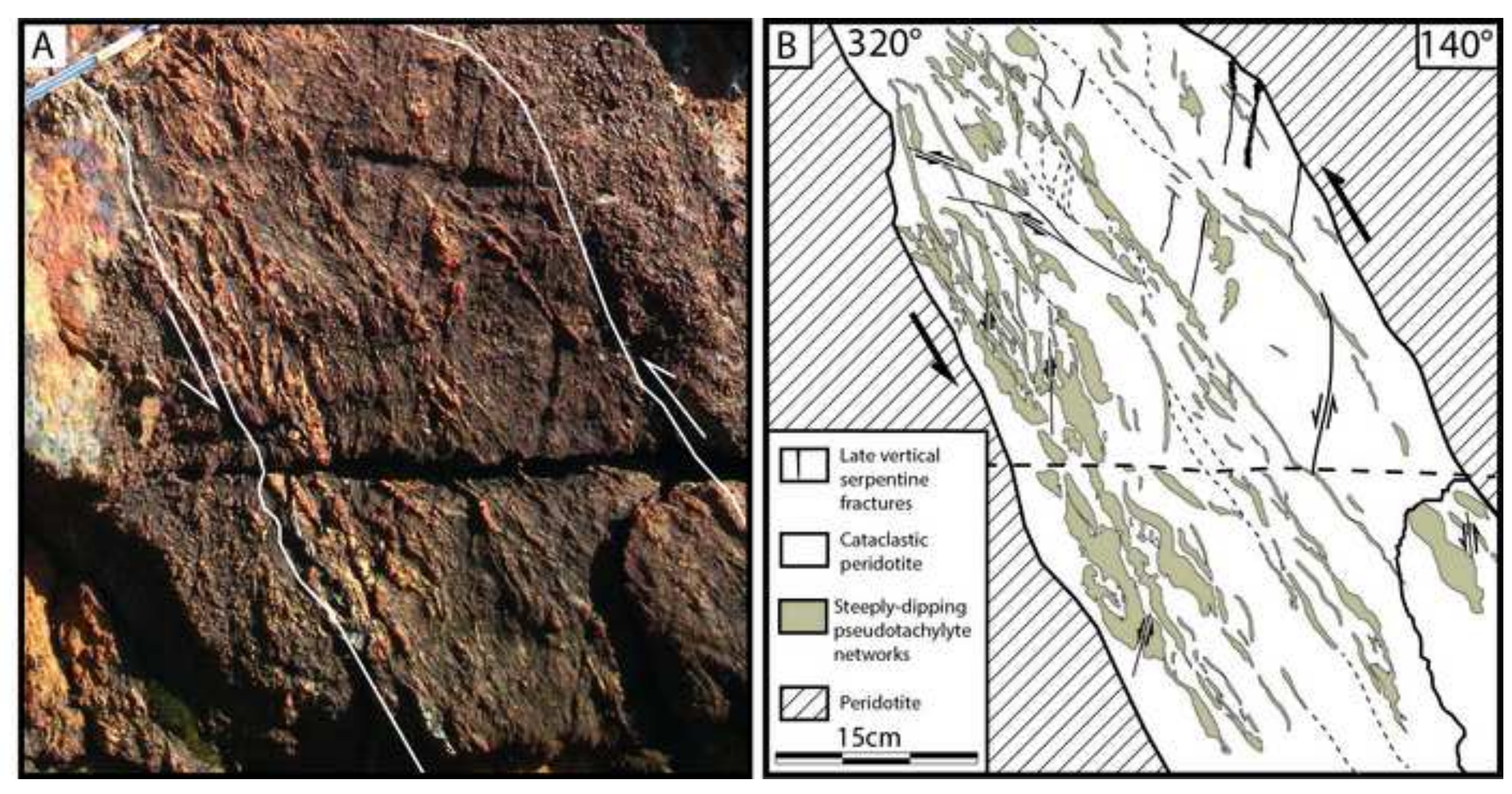

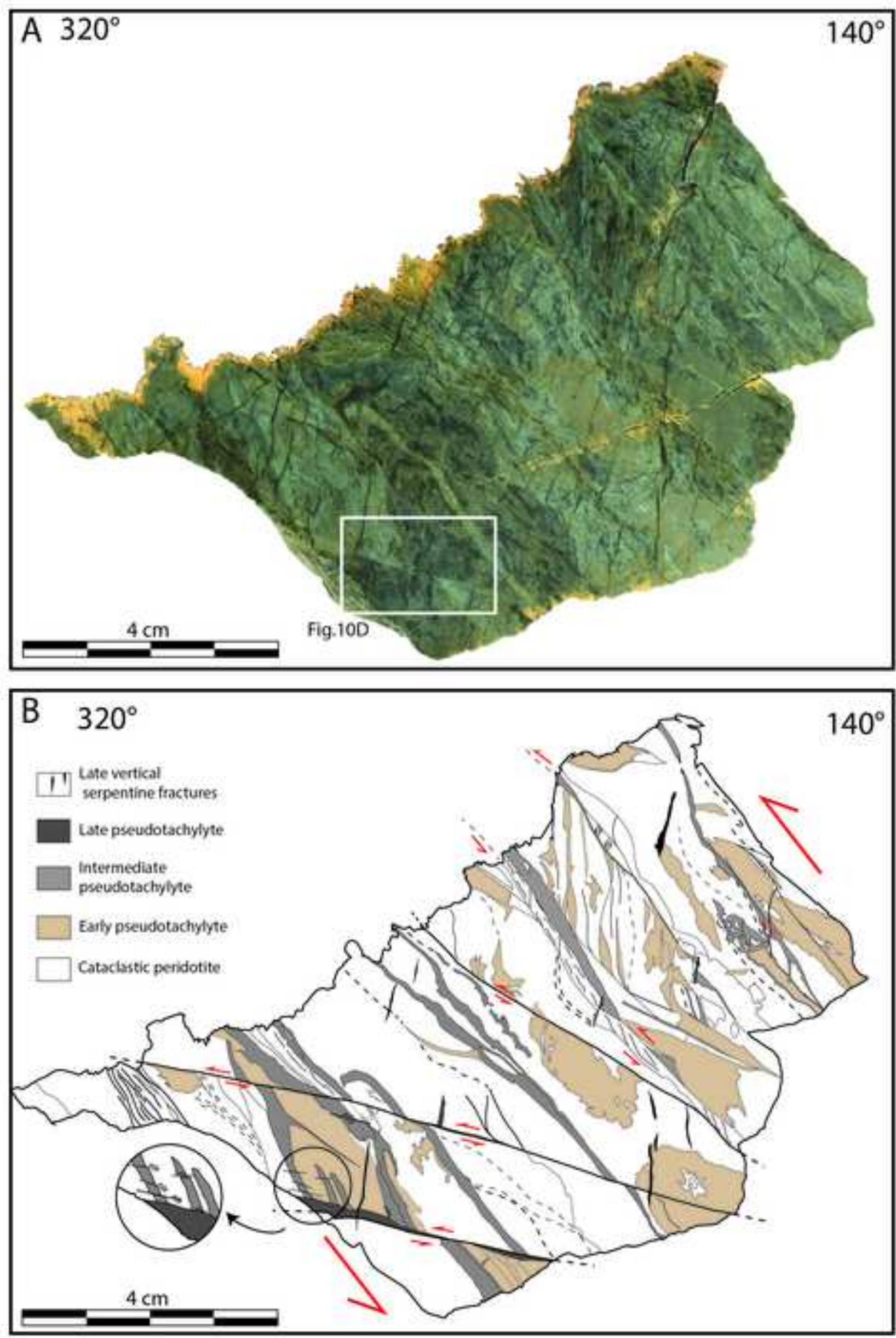

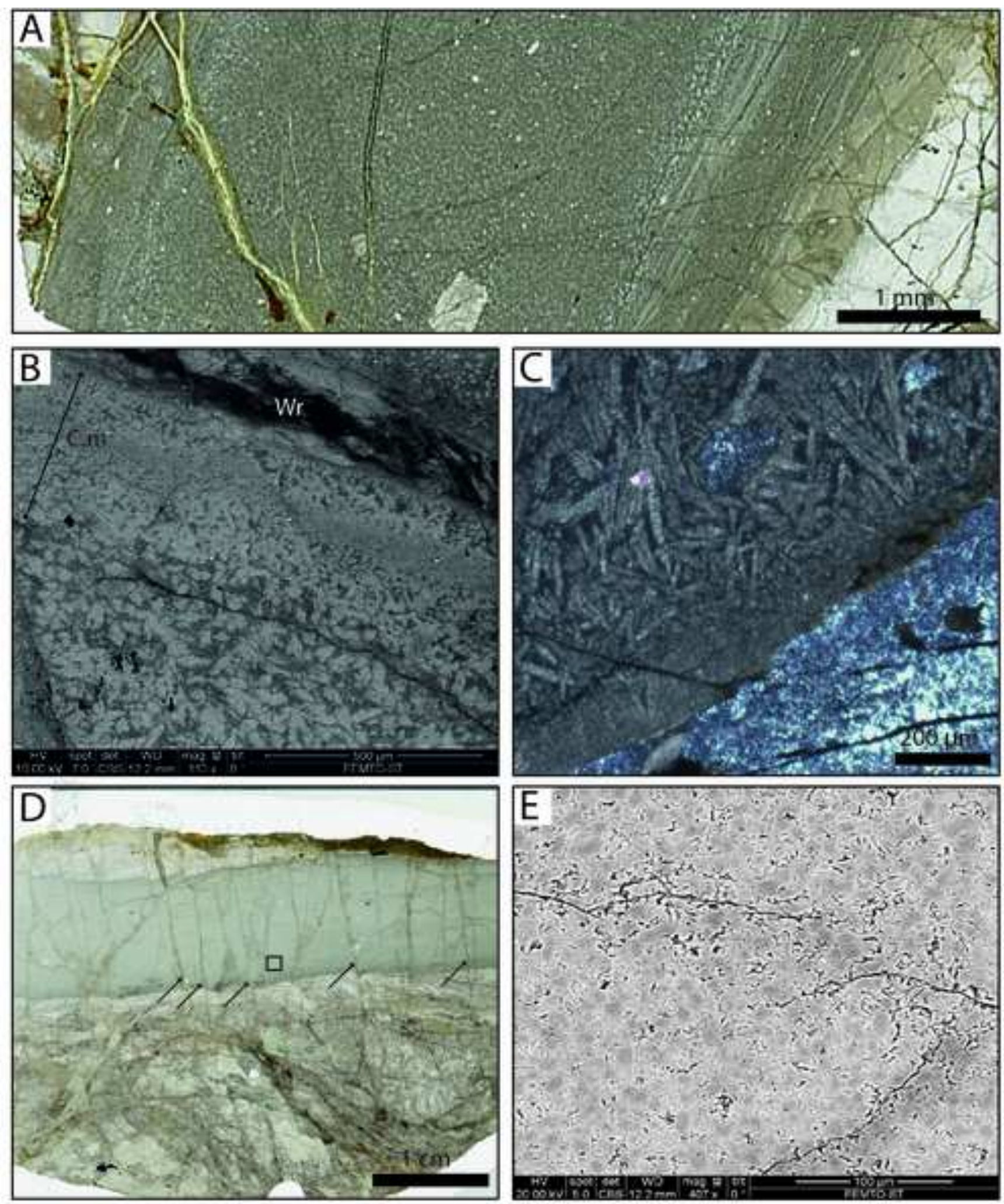
Click here to download high resolution image
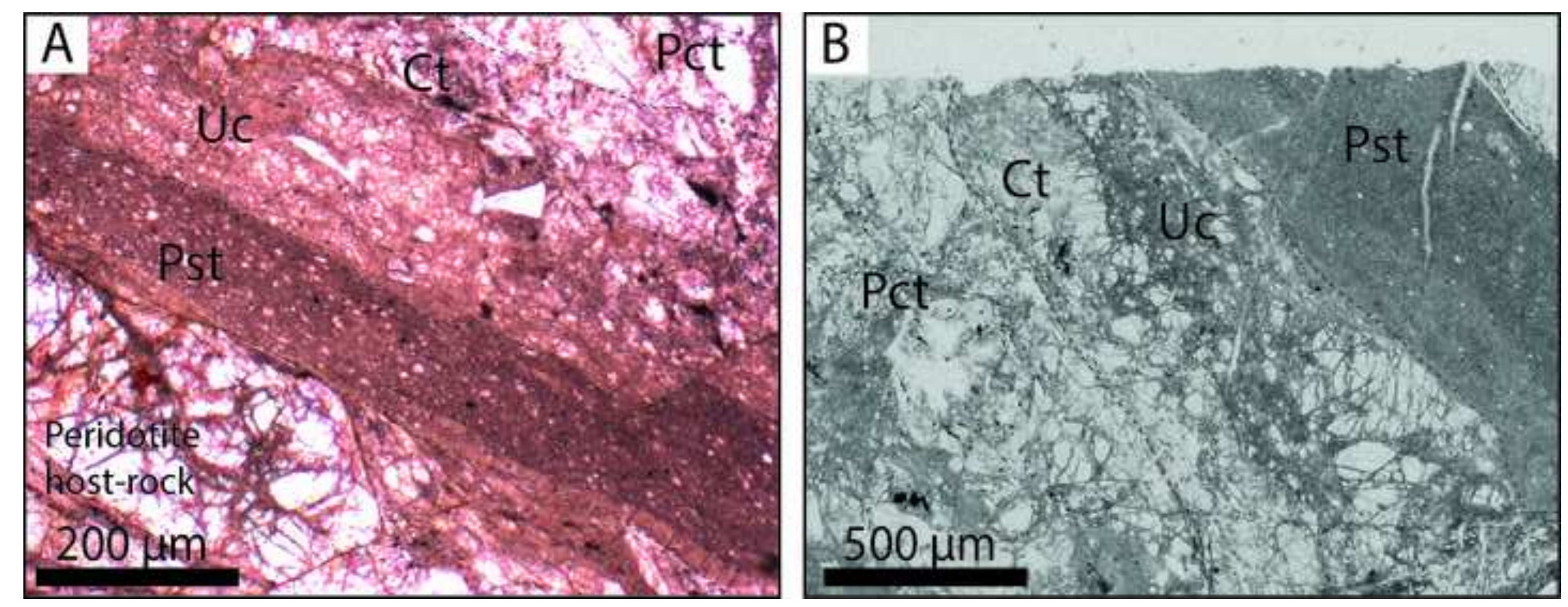
Click here to download high resolution image
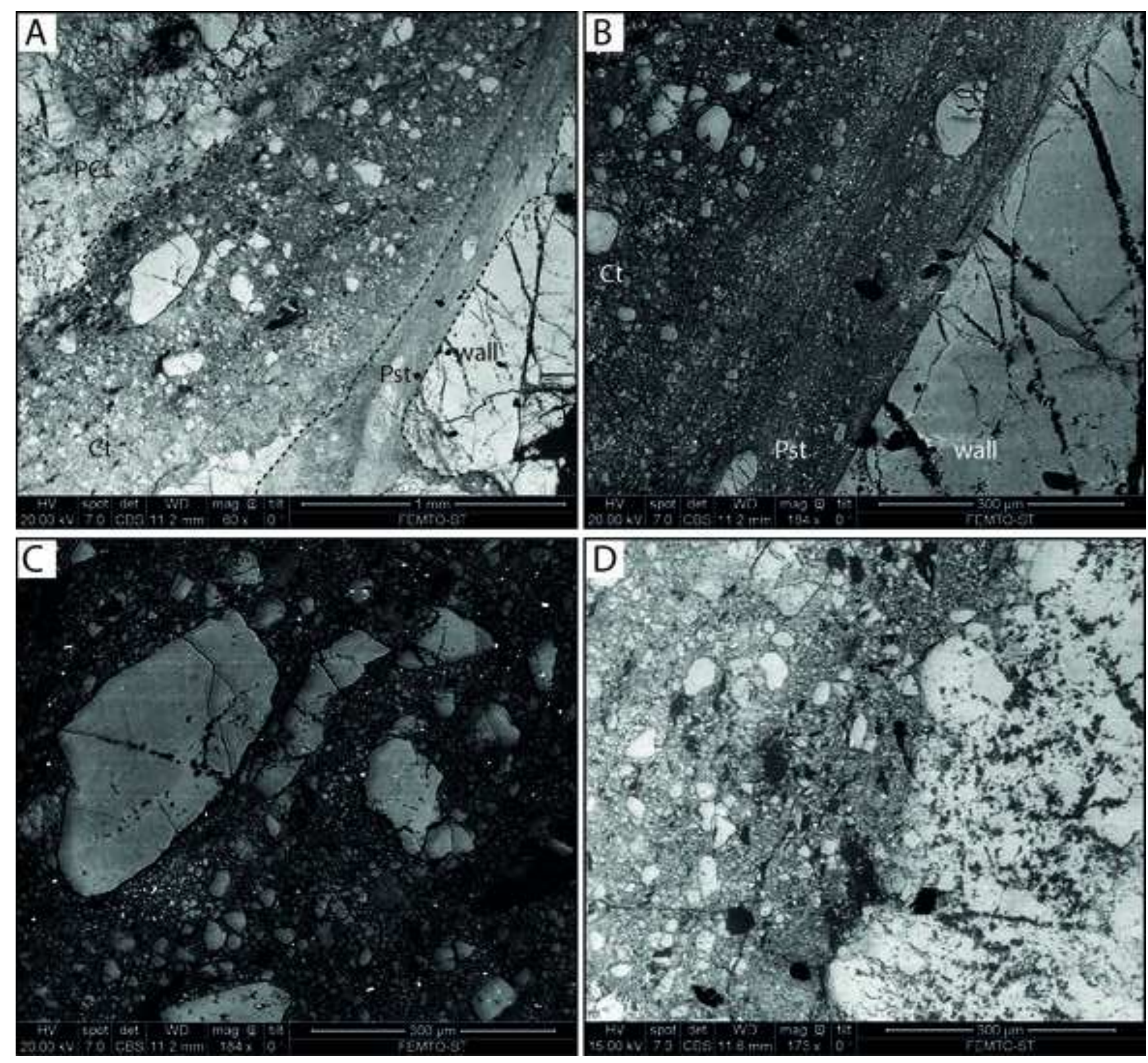

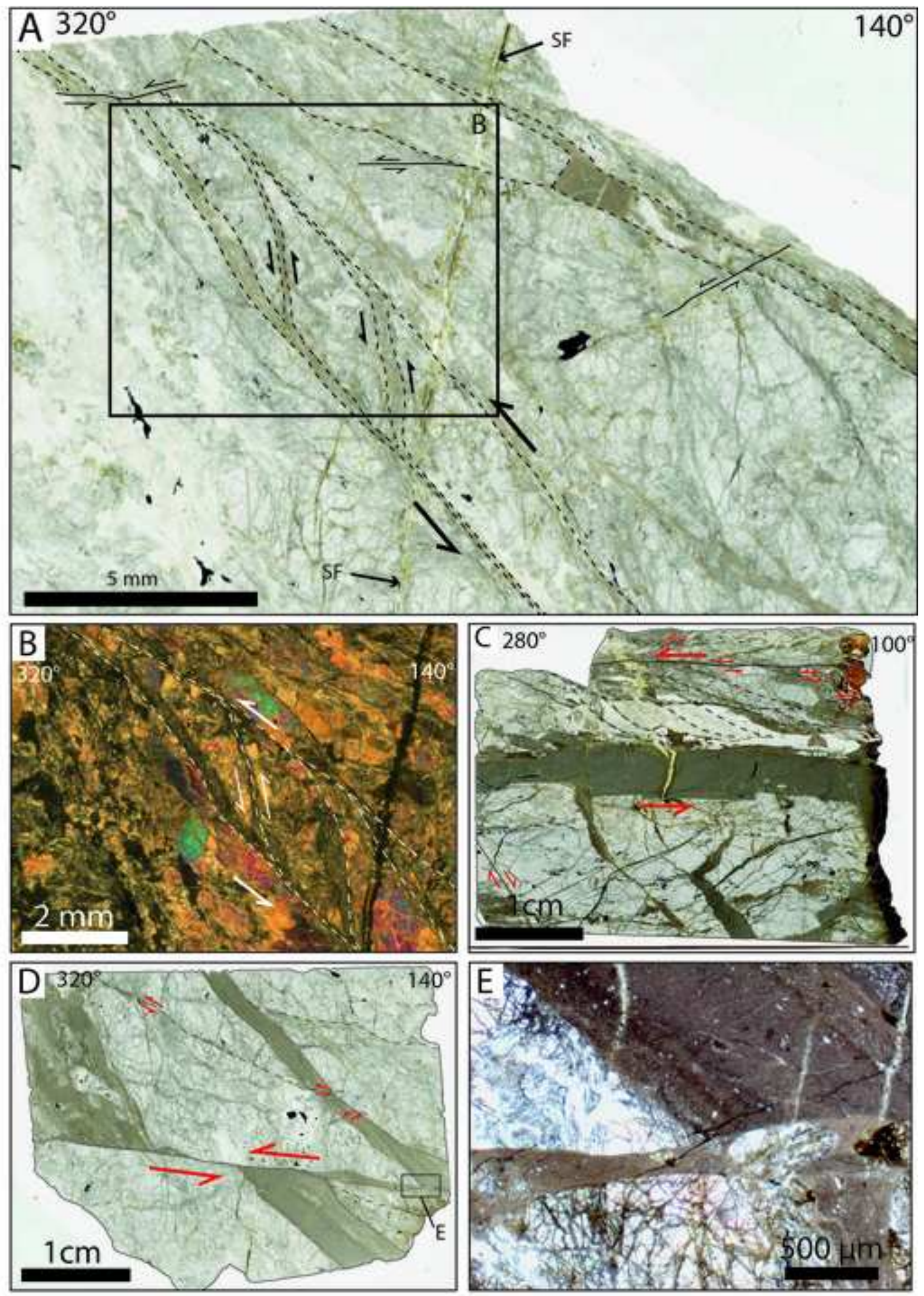
Click here to download high resolution image
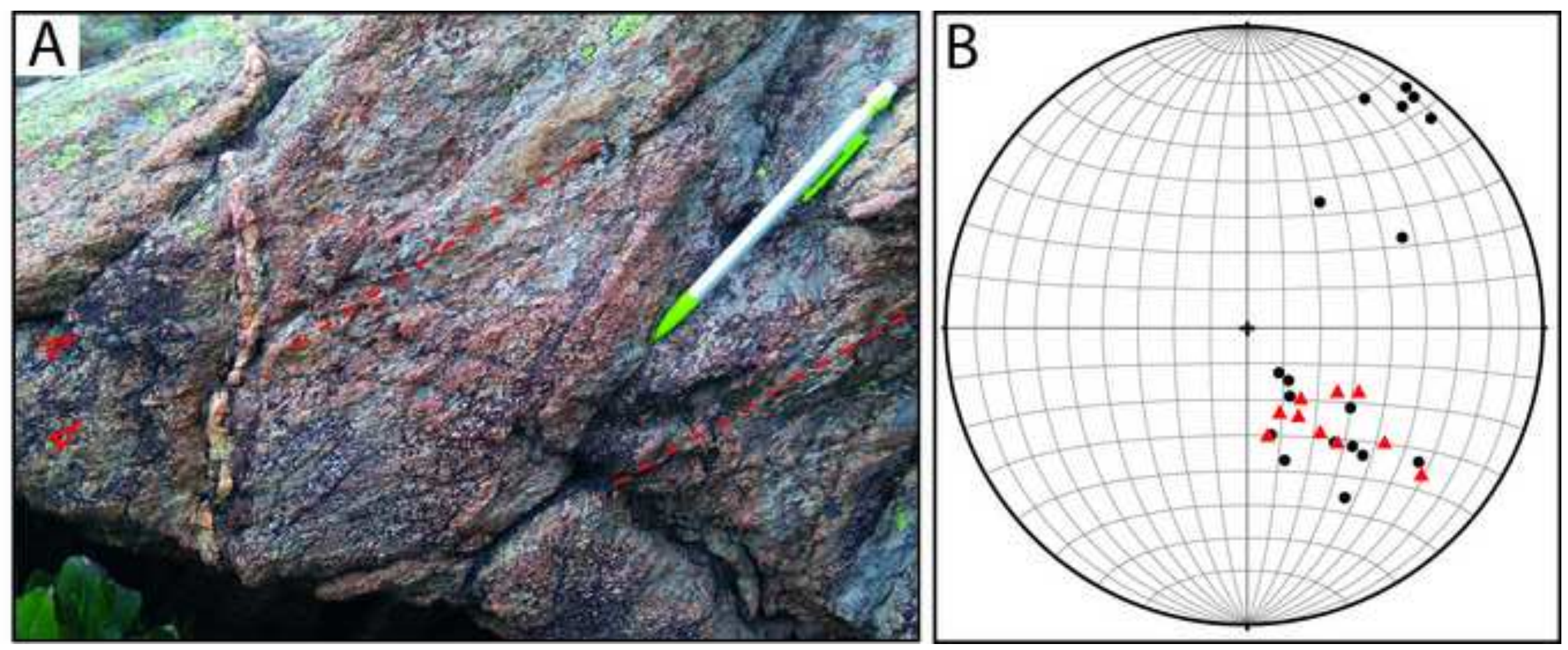
Click here to download high resolution image



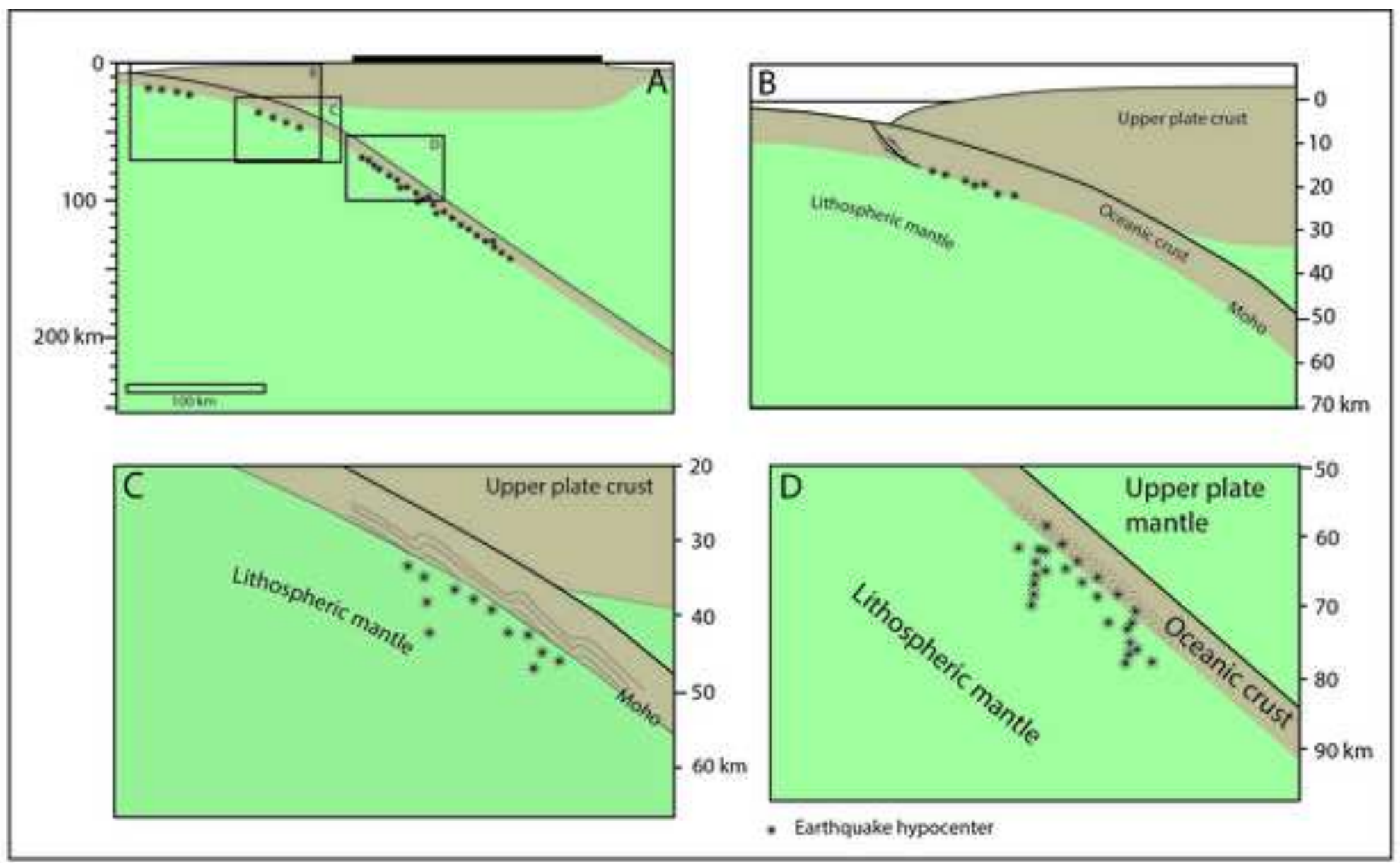


Click here to download high resolution image
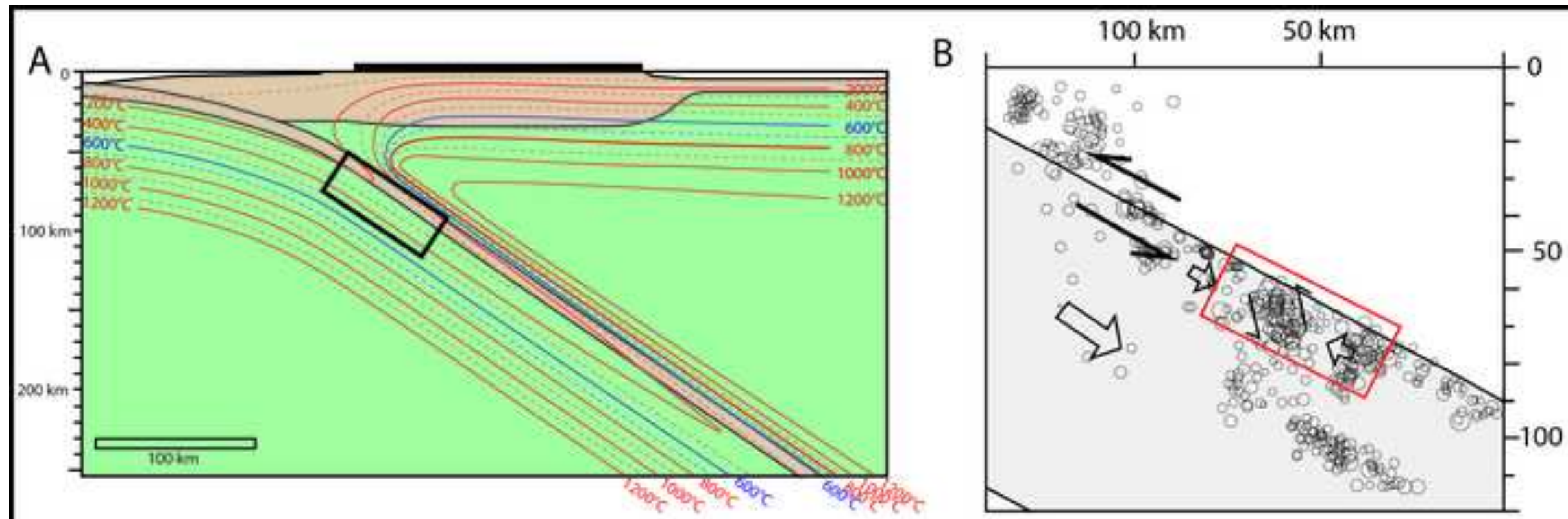

C

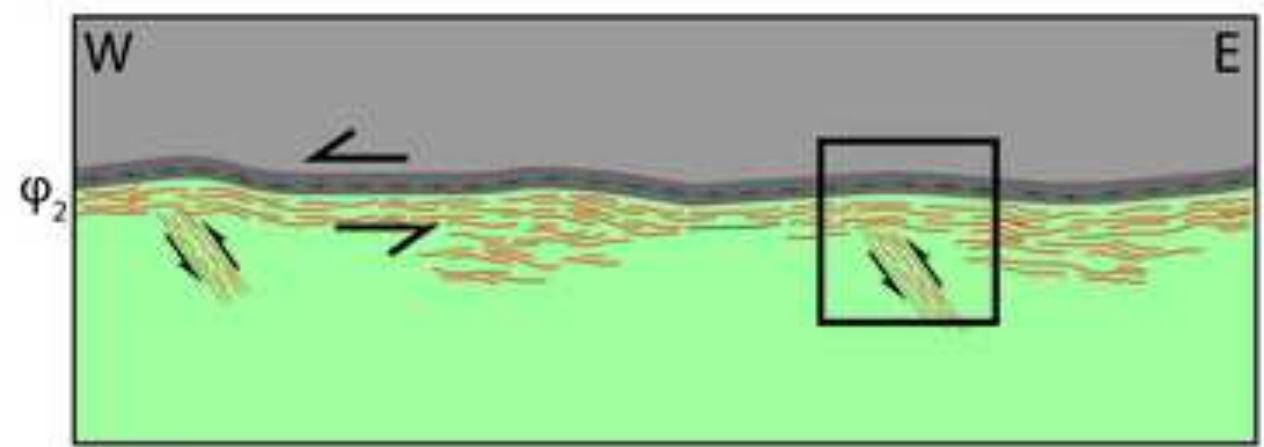

Peridotite
Metagabbro / foliated metagabbro

$\square$ Peridotite-hosted pseudotachylyte fault zone

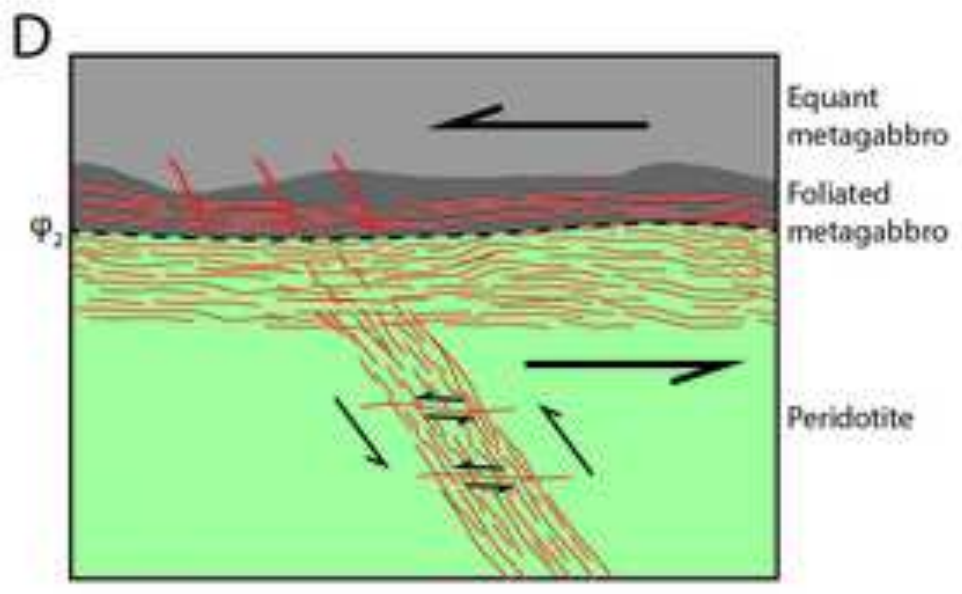

